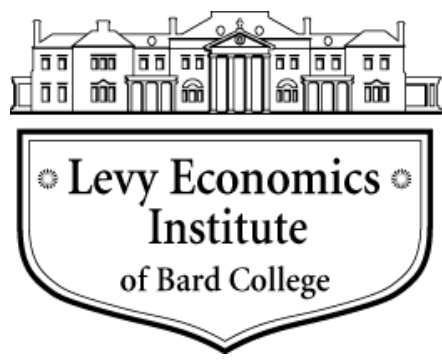

Working Paper No. 997

\title{
Identity and Well-Being in the Skilled Crafts and Trades
}

by

\author{
Martin Binder \\ Levy Institute \\ and \\ Universität der Bundeswehr München
}

and

\section{Ann-Kathrin Blankenberg \\ Bard College Berlin}

\section{December 2021}

The Levy Economics Institute Working Paper Collection presents research in progress by Levy Institute scholars and conference participants. The purpose of the series is to disseminate ideas to and elicit comments from academics and professionals.

Levy Economics Institute of Bard College, founded in 1986, is a nonprofit, nonpartisan, independently funded research organization devoted to public service. Through scholarship and economic research it generates viable, effective public policy responses to important economic problems that profoundly affect the quality of life in the United States and abroad.

Levy Economics Institute

P.O. Box 5000

Annandale-on-Hudson, NY 12504-5000

http://www.levyinstitute.org

Copyright (C) Levy Economics Institute 2021 All rights reserved

ISSN 1547-366X 


\begin{abstract}
We analyze the extent to which occupational identity is conducive to worker well-being. Using a unique survey dataset of individuals working in the German skilled crafts and trades (2017-18, $n=757$ ), we use a novel occupational identity measure that captures identity more broadly than just referring to organizational identification and social group membership, but rather comprises personal and relational elements inherent in one's work. The latter are linked to significant social interactions a worker has in their job and the former to specific work characteristics of the work conducted itself. We find that higher job satisfaction is related to a stronger sense of occupational identity in our sample. This relationship is quite sizable and robust across model specifications, whereas income is not associated with job satisfaction in most models. Occupational identity is positively associated with a number of work characteristics, viz. task significance, task and skill variety, as well as social support, and our analysis shows that identity mediates the influence of these characteristics with regard to job satisfaction.
\end{abstract}

KEYWORDS: Occupational Identity; Identity Utility; Job Satisfaction; Crafts; Work Characteristics

JEL CLASSIFICATIONS: J28; J24; I31; B55 


\section{INTRODUCTION}

Not all jobs are created equal. For some people, their job is just a means to finance their lives outside of work. For others, their work is more than a paycheck to compensate for the disutility of work; for them, work is something that allows them to express themselves. In times where employees increasingly report experiencing their work as meaningless and "bullshit" (Graeber 2018), it is both timely and important for public policy to better understand what facets of work allow one to express themselves, develop a strong occupational identity, and experience work as satisfying. Such an understanding is also important for employers, as job satisfaction has been linked to increased worker productivity and employee retention (see Fisher [2010] for a survey).

In economics, the role of "occupational identity" has been explored with regard to worker motivation and supervision (Akerlof and Kranton 2005, 2008), ${ }^{1}$ but much of the work in "identity economics" and the literature on organizational identification (Mael and Ashforth 1992; Ashforth, Harrison, and Corley 2008) conceives of identity as solely derived from social group membership (being part of an organization or other social category; see Tajfel [1974]). Our work starts with the seminal model of identity utility of Akerlof and Kranton (2000, 2005), who also focus on social group membership, but we modify it to incorporate identity utility not primarily derived from being part of a social group.

Our paper is the first to focus on the personal and the relational (interpersonal) elements that contribute to an "occupational identity," which is derived from work characteristics related to a specific type of work itself (as measured by skill variety, task significance, how holistic a work task is, how much autonomy and social support one has, and others; see Morgeson and Humphrey [2006] and Humphrey, Nahrgang, and Morgeson [2007]). Our paper is also novel in that it is the first to analyze worker well-being in the skilled crafts and trades and it counts itself among a very small number of papers that link a more general occupational identity measure to worker well-being: with the exception of Wegge et al. (2006) and Berg (2017) previous work has

\footnotetext{
${ }^{1}$ Identity more generally is also analyzed with regard to its impact on economic preferences (Benjamin, Choi, and Strickland 2010) and how it can lead to in-group favoritism within groups (Eckel and Grossman 2005; Ben-Ner et al. 2009). This can extend to large groups in the case of national identity (Caruso, Di Domizio, and Savage 2017) or even a European identity (Verhaegen, Hooghe, and Quintelier 2014).
} 
focused solely on a much narrower idea of "organizational identification" (see Riketta and Van Dick 2005; Lee, Park, and Koo 2015).

In addition, to our knowledge, we are the first to provide evidence that the well-known relationship between work characteristics and worker well-being is mediated by occupational identity, i.e., work-specific characteristics help foster a strong sense of occupational identity, which in turn leads to improved worker well-being. In contrast to a standard model that places income center-stage for worker well-being, we can also show how occupational identity and work characteristics are more strongly and consistently related to job well-being than a worker's income. Our findings can substantively explain why some types of occupations are more wellbeing enhancing than others.

Lastly, our work is original in providing a first test for the distinction introduced by Akerlof and Kranton (2005) between absolute identity-related utility versus a norm-related, relative element, where part of one's utility is derived from exhibiting effort levels at work commensurate with the ideals associated with the group one belongs to and identifies with. We compute identity reference categories and measure the deviation of individuals in terms of hours worked and intrinsic motivation to capture this elusive norm-related element.

Our paper deals with the occupational identity of workers in the skilled crafts and trades and uses a unique and novel dataset for German craftworkers that has detailed information on work characteristics and well-being and a novel measure of occupational identity, which is not available in big household panel surveys on the German workforce (such as the Socioeconomic Panel Survey [SOEP]). Our focus on the German crafts sector is highly relevant as the crafts sector is a core sector of the German economy with 26.8 percent $(999,954)$ of all firms being part of it (ZDH 2017) and welfare effects pertain to a sizable part of the working populace, as the crafts sector employs 12.4 percent (5.49 million) of all employees and 27.6 percent of all apprentices in Germany (ZDH 2017). Working in the crafts sector can also be distinguished from many other jobs by work characteristics that suggest it may foster a strong sense of occupational identity: workers in the crafts are able to see the results of their work, have the opportunity to produce the entire work piece (not just a small part of it), create and craft it as reflective of their personality, and ultimately perceive their work as producing something useful and hence 
genuinely meaningful (Crawford 2010). In addition, craftwork is characterized by strong bonds between the master craftsman and their apprentices in an apprenticeship system centered around learning by doing (Marchand 2008; Chan 2014; Klotz, Billett, and Winther 2014). With these characteristics of work then comes "the desire to do a job well for its own sake" (Sennett 2008, 9 ), the taking pride ${ }^{2}$ in one's work product, and the cultivation of a specific identity as a craftsman or woman. ${ }^{3}$ While such a role of identity in the crafts and trades has been researched in parts in qualitative case studies, our study is the first to empirically quantify such a crafts-related identity across a sample of crafters and relate it to their job satisfaction.

The remainder of the paper is structured as follows. Section 2 presents a brief formal model to organize the exposition of the literature background and development of research questions in section 3. Section 4 introduces our dataset, followed by the analysis in sections 5 and 6 . We conclude in section 7 .

\section{THEORETICAL MODEL}

A simple model of a worker's utility function assumes that a worker derives disutility from the effort, $e$, expended at work (which is considered a nuisance compared to leisure). A wage, $w$, is therefore being paid to compensate for this disutility. In this utility function,

$$
u=u(w, e)
$$

utility positively depends on wage $\left(u_{w}>0\right)$ and negatively on effort $\left(u_{e}<0\right)$. This formulation is too simple, as worker utility may also depend on other factors $\left(z_{i}\right)$, which have been identified in psychological, sociological, and economic literatures, such as gender, education, or characteristics of the work itself including task variety, task significance, or autonomy at work (we will discuss these in more detail later).

\footnotetext{
${ }^{2}$ Hence also the German "Handwerksstolz": being proud of one's craft. Compare similarly the notion of craftsmen considering themselves to be "the salt of the earth" (Dickie 2003, 258).

${ }^{3}$ Only 17 percent of our sample are women, a proportion similar to the overall gender distribution in the crafts sector in Germany. In the following, for better readability, we use the terms "craftsman" to refer to both genders.
} 
We follow Akerlof and Kranton (2005) in modelling worker utility with an extended utility function, where worker identity $I_{c}$, as well as other factors $z_{i}$ play a role for individual worker motivation and well-being. In this extended utility function,

$$
u=u\left(w, e, z_{i} ; c\right)=\ln w-e+I_{c}-t_{i, c}\left|e^{*}(c)-e_{i}\right|+z_{i},
$$

in addition to the factors in equation (1), the individual can reap "identity utility" from belonging to a certain social category, $c$, that captures their work-related identity (in a simple case, this could mean they consider themselves to be "insiders" to the firm or "outsiders," i.e., they identify with the firm's goals and values or not; this follows Akerlof and Kranton [2000, 2005]). Identity utility here has an absolute component, $I_{c}$, from belonging to the relevant (social or personal) identity category, $c$, but it also has a relative, norm-related element, $t_{i, c}\left|e^{*}(c)-e_{i}\right|$, where utility depends on a person's deviation in terms of effort from an ideal effort level, $e^{*}(c)$, associated with the relevant identity ( $t_{i, c}$ models the importance an individual ascribes to living up to this ideal level and modifies the utility loss from deviation from the ideal level). The extended utility function also specifies the increase in utility from wage to be log shaped, to account for the decreasing marginal utility of income. We further extend the utility function to account for additional nonpecuniary aspects, $z_{i}$, of the job that have been identified as relevant to worker utility. Our focus in this paper is mostly on measuring $I_{c}$, but we also offer some exploration on the effect of the relative component, $t_{i, c}\left|e^{*}(c)-e_{i}\right|$.

In Akerlof and Kranton's model (as in every utility function; see Kahneman, Wakker, and Sarin 1997), there is some ambiguity as to whether utility refers to motivation ("decision utility") or evaluation (welfare; "experienced utility"). While Akerlof and Kranton $(2005,9)$ initially refer to people "feel[ing] bad" from not conforming to the norms associated with some social category they belong to, and hence to the evaluative interpretation of the utility function, in Akerlof and Kranton $(2010,23)$, the authors state that their model aims at capturing the motivational aspects of utility (preference/behavior), not its meaning of utility as welfare. Here we complement the focus of Akerlof and Kranton by interpreting utility as welfare. Our use of the model above thus differs in that we are not interested in how identity shapes behavior, but rather in the interpretation of "feeling good" from having an identity $c$. We also interpret $I_{c}$ more broadly, so 
that $c$ does not have to refer to social categories but rather encompasses relational and personal aspects of a worker's identity. By this we go beyond the social identity literature of organizational identification (Ashforth, Harrison, and Corley 2008; Haslam 2004: appx 1).

\section{LITERATURE BACKGROUND: WORK AND WELL-BEING}

In order to motivate the above model for the context of the crafts sector, in subsection 3.1 we will proceed to identify factors likely relevant in influencing a worker's well-being. Due to our interest in the welfare interpretation of equation (2), we model worker utility as job satisfaction, the study of which has a long tradition (e.g., Freeman 1978; Warr 1992; Clark, Oswald, and Warr 1996). As the literature on occupational identity is both "fragmented" and "haphazard" on the theoretical level (Miscenko and Day 2016, 216), and mostly centered around organizational identification on the empirical level, we will then discuss the notion of "identity" and its expression at work in subsection 3.2. This allows us to delineate in subsection 3.3 how crafts are a special type of work that give rise to a specific form of (nonorganizational) occupational identity. Based on this discussion, we derive hypotheses to test with our dataset.

\subsection{Well-Being At Work}

There is a large literature connecting job satisfaction to its determinants both inside economics and outside of it (for reviews see, for instance, Judge and Klinger [2007] and Fisher [2010]). With regard to the model above, the empirical support for a big role for wage in job satisfaction has proven to be moderate (Judge et al. 2010), whereas other factors have been shown to be more consistently and strongly related to job satisfaction. These range from sociodemographic factors to characteristics of the work itself as well as dispositional factors (Fisher 2010, 395). While job satisfaction itself may also influence some of these determinants, the predominant theoretical explanations see the causal arrow running from said factors to job satisfaction.

The most important sociodemographic factors are age (u-shaped, see Clark, Oswald, and Warr [1996]), gender (women are often found happier in their jobs, see, e.g., Clark [1997]), and

education (mixed evidence, often driven by mismatch between education and job demands as well as aspirations, e.g., Vila and Garcia-Mora [2005]). 
Work characteristics associated with job satisfaction are hours worked (typically negative) (Clark, Oswald, and Warr 1996), full-time versus part-time work (D’Addio, Eriksson, and Frijters 2007), firm size (Idson 1990), and industry sector (for instance working in the public sector) (D’Addio, Eriksson, and Frijters 2007). Following the job characteristics model (Hackman and Oldham 1975, 1976), five core motivational work characteristics have also been identified as important for job satisfaction, namely task identity, task significance, task variety, autonomy, and work feedback (e.g., Humphrey, Nahrgang, and Morgeson 2007). Building on this taxonomy, Morgeson and Humphrey (2006) extended work characteristics into the knowledge domain (job complexity, specialization, skill variety, problem-solving etc.) and identified social characteristics (e.g., social support, interdependence, feedback from others), which have recently gained much recognition in terms of their contribution to workplace well-being (Judge and Kammeyer-Mueller 2012; Humphrey, Nahrgang, and Morgeson 2007).

Within the last category of dispositional characteristics, personality traits and intrinsic work motivation have been shown to be related to job satisfaction (positive for intrinsic motivation, extraversion and less robustly so conscientiousness, negative for neuroticism; see Judge, Heller, and Mount 2002; Clark, Oswald, and Warr 1996); other work values include "core evaluations" (basic dispositions and value judgements of the individual, for instance, self-esteem; see Judge and Bono [2001]), which are related to personality traits and can also bridge the gap to the abovecited notion of occupational identity.

"Occupational identity" would belong to this latter category of dispositions, even though other work characteristics may shape it, and it may offer a useful organizing framework for these (related to an individual's self-concept and dispositions and values, see below). Based on a theory-driven consensus for a positive role for a strong, "self-chosen" identity for job satisfaction (Christiansen 1999; Skorikov and Vondracek 2011), empirical studies were able to provide evidence for this relationship (for meta-analytic evidence, see Riketta and Van Dick [2005] and Lee, Park, and Koo [2015]), but predominantly so on the level of "organizational identification" (i.e., making the organization's identity one's own). For instance, in an early study, Hall and Mansfield (1971) have shown that having one's organizational identification threatened through external events decreases job satisfaction. Other evidence comes from studies in different organizations, for instance, from a study of Dutch government workers and university employees 
(Van Knippenberg and Van Schie 2000) or from German bank and travel agency employees (Van Dick et al. 2008), where the authors found positive correlations between workgroup and organizational identification and job satisfaction (with workgroup identification more strongly predictive of job satisfaction). These studies focus on social identity (either on the organizational or workgroup level), but very few are related to a broader notion of occupational identity (Berg 2017; Klotz, Billett, and Winther 2014; Dabke et al. 2008), or relate personal identity to specific tasks and work characteristics (Wegge et al. 2006). Finally, most studies focus on non-craftwork types, leaving open the extent to which those results apply to the specifics of the crafts sector. Based on the above, we hypothesize that: Occupational identity positively affects job satisfaction (H1).

\subsection{Identity At Work}

Our identity, who we are, determines what we do and how we perceive and experience our actions; it answers the question "Who am I?" (Ashforth, Harrison, and Corley 2008, 327). We can define "identity" (or synonymously "self-image") as "a person's sense of self" (Akerlof and Kranton 2000, 715) or the "label[s] used to describe oneself" (Whitmarsh and O'Neill 2010, 306). In a broad sense, identity is a narrative that refers to a person's self-concept, their system of values, goals, and beliefs (Steg 2015), but may also encompass their skills, knowledge, and abilities as content of said identity (Ashforth, Harrison, and Corley 2008, 330). ${ }^{4}$ While many occupational identity concepts are predominantly cognitively centered (identity as self-concept), Ashforth, Harrison, and Corley $(2008,330)$ have recently argued that the core of identity also includes affective and evaluative elements: identity is not only "I am A" (self-concept/definition), but also "I value A" (importance) and "I feel about A" (affect). The latter is reflected, for instance, in one's pride in what one is or does. Despite arguably having affective elements, identity as a broad set of (often stable) attitudes about who one is, is separate from a concept such as job satisfaction, which is a judgement-cum-endorsement or affirmation (Haybron 2007, 102) of how one's job is going and how satisfied one is with the job (compare for instance Haslam [2004, 69 and 76]).

\footnotetext{
${ }^{4}$ There may not be one identity, however, but rather multiple (social) identities, which are activated in different social contexts (Akerlof and Kranton 2010). This is especially relevant in our case, where one may have the identity of a craftsman, clerk, or a professor, each of which can encompass values and actions different from those lived outside of work.
} 
Identity theories in economics mostly stress the social group element (Akerlof and Kranton 2000, 2010), where social identity is defined as "that part of the individuals' self-concept which derives from their knowledge of their membership of a social group (or groups) together with the value and emotional significance of that membership" (Tajfel 1981, 255), in our case, being part of the craft profession, or belonging to the group of certified master craftsmen in one's field. Social identity is sometimes also further distinguished in "collective" (self-proclaimed social category/group membership) versus "interpersonal/relational" identity ("personalized bonds in dyadic relationships"; see Miscenko and Day [2016, 217]). Boundaries here are often not clearly distinguishable and are contested (Miscenko and Day 2016). In the following, we will argue that a focus only on the collective level may ignore important elements of personal identity, where personal identity is derived from unique traits and characteristics of the individual and the work they do, i.e., a person's self-concept not directly related to social group membership. In the craft profession, this type of identity may derive from identification with one's work process and work product.

With the central role of work in our societies, occupational identity can be an important part of individuals' overarching identity (Kroger 2006; Skorikov and Vondracek 2011, 697). The practice of work and its ascribed meanings define the daily life of every working person in many ways. Work contributes to "a sense of being something (at minimum, being a productive person)" and it "seems critical to perceptions of belonging and status as well as one's sense of personal worth" (Dickie 2003, 251), thus allowing the worker to be a particular person (Christiansen 1999). The literature on occupational identity has identified various antecedents that may determine an individual's identity at work, including individual activities and experiences, personality, gender, family and peers, modern social and economic conditions, and more (Skorikov and Vondracek 2011).

\subsection{Identity in the Crafts Profession}

In addition to the above-mentioned antecedents, the occupational identity of a crafts(wo)man can be shown to include elements of (1) collective, (2) relational, and (3) personal identity that are specific to the skilled crafts and trades. 
In terms of collective identity (1), above all, craftsmen tend to see themselves primarily as carriers of a profession, whose ethos is expressed in all their professional behavior (Roessle 1964, 24: cited in Sandgruber, Bichler-Ripfel, and Walcher 2016). Cramer and Müller (2011) argue that in Germany, in the last centuries, a strong identity of belonging to the crafts was achieved through common socialization and the awareness of it, starting with the access to the profession via apprenticeship in the dual training system, ${ }^{5}$ followed by journeyman's work and its culmination in the master school and the acquisition of a "Grand Certificate of Competence" ("Meisterbrief"). The certificate acted as a prerequisite for independence, allowing one to run their own business and to train apprentices, thus continuing the socialization chain. The common identity thus created found its expression, for example, in the cultivation of similar lifestyles, ${ }^{6}$ in a sense of quality in craftsmanship, a sense of responsibility for the local common good and, among other things, in guild membership (Cramer and Müller 2011). The amendment of the Trade and Crafts Code ("Handwerksordnung") in 2004 has considerably relaxed the conditions for access to the crafts sector and led to, amongst other things, a weakening of this socialization chain, potentially undermining this element of common occupational identity (Cramer and Müller 2011). ${ }^{7}$

On the relational level (2), craft-related identity may be derived from interaction with colleagues (e.g., "workgroup identity," see Riketta and Van Dick [2005]). The most prominent dyadic relationship here is certainly on the level between master craftsman and apprentice (or journeyman and apprentice), who jointly work on their craft for a long time, as learning takes place through doing and imitating one's master (Marchand 2008; Chan 2014). Successful learning also cements positive relations and positive interactions then foster specific occupational identity. Through features of the work itself, to be discussed more extensively below, the

\footnotetext{
${ }^{5}$ The German dual training system refers to apprentices both being trained in their company on the job as well as going to trade school in parallel for other aspects of their training.

${ }^{6}$ The travelling journeyman ("Wanderschaft") was a tradition cultivated for a long time. One of its fundamental aims was to give the journeyman the necessary professional and personal maturity before they were admitted to the "master craftsman examination" (Bade 1982). Such travel led to a transfer of technology and the continuous learning and development of skills (Bade 1982, 3). The practice had already lost influence by the end of the 18th century and, while no longer common practice today, some craftsmen still travel the country in a special garb and learn and proclaim their identity as unique group of workmen.

${ }^{7}$ Collective identity might also pertain to the firm in which a craftsman works (this is closest to Akerlof and Kranton's examples and model), but this is not specific to the crafts.
} 
relationship between master craftsman and apprentice has a strong formative effect on the apprentice (Rosensträter 1964).

A similar relational element has also been described as identity-building in terms of the relation between the craftsman and the client, for whom a product is being made: direct feedback from clients here contributes to this source of (relational) occupational identity (as compared to other occupations, where workers may get no direct feedback and no potential appreciation of the final work product).

In this paper, we are mostly interested in occupational identity deriving from the personal level (3), viz. where identity is linked to the specific work done and the work characteristics associated with it. Crafts, in contrast to other modern work types, can be described as a form of work with specific characteristics in terms of work activities and work demands (Roessle 1964: cited in Sandgruber, Bichler-Ripfel, and Walcher 2016). And while the crafts can be characterized as polythetic (Marchand 2016), i.e., each individual craft is different from other crafts, they nevertheless all share some joint characteristics in terms of skills, processes, and challenges, which foster a personal identity as a craftsman (e.g., Corson 1985, 295).

Most of the meaning ascribed to the craftsman's work and to the resulting occupational identity can be traced to individual characteristics of the work product, work process, and the person's relation to those. Central for identity development here are the (a) embodied aspects of the work and work knowledge (Marchand 2012), the (b) tangible aspects of craftwork (Thurnell-Read 2014,19 ), and the (c) acquisition and practice of skills (often not neatly separable, as even masters still stretch the boundaries of their expertise; see Marchand [2010b]). Related to (a), the literature has characterized work in the crafts as distinct from many other jobs (such as the service industry) through its strong connection to "embodied cognition" (Marchand 2010a; Gaertner 2013), what Marchand (2012) calls "knowledge in hands": much of the craftsman's skills and knowledge is not of a propositional nature ("I know that ...") but is tacit ("I know how ..."; see Polanyi [1962 (2005)]), involving, for instance, motor skills and learning that cannot be transmitted by textbooks, but through doing and observing others practice their craft (Marchand 2010a). 
"Knowledge in hands" is embedded in the craftsman's body (hands mostly, but also other body parts), including the tools used, which become extensions of one's body and of which craftsmen lose awareness when focused on the object of their craft (O'Connor 2005; Marchand 2012; Polanyi 1962 (2005), 61). This physical immersion that is inherent in embodied cognition (Marchand 2008,264) relates also to the materials worked with from early apprenticeship onwards, and which create a sense of closeness to the craft. Using their specialized skills in addition to special, often personal, tools, and working with (not upon) "their" materials has been described as evoking a sense of unity or "holisticity" (Pöllänen 2013) and the experience of "being in the zone" (Marchand 2012, 264). In effect, this fosters a specific crafts-related identity.

Related to this, the personal aspects of occupational identity have also been shown to be tightly linked to the tangible aspects (b) of a craftsman's work. This concerns both the tangibility of process and outcome (Thurnell-Read 2014, 19); on the outcome level is the work product, which often is a direct expression of the craftsman (think of different pottery styles or a chef's signature dishes, see, e.g., Inkson [1987, 173]). Being able to craft the product of their designs thus brings a tangible reward in the form of the artefact created and entails a sense of achievement in the face of a real risk of failure of the work process (Pöllänen 2013, 221). There is also a visible component insofar as the creator often gets feedback and sees whether their customers like and enjoy the outcome of their craft. Such a strong relationship to the product leads to identification with it and with the craft, something that is also enhanced and reinforced through the tangibility of the craft process itself: tangibility of the craft process comes from the sensory nature of the craft process (for instance seeing, touching, and smelling the ingredients when brewing beer, baking bread and cakes, crafting a shoe, blowing glass [Thurnell-Read 2014; Chan 2014; Braithwaite 2017; O'Connor 2005]), and is described as the opposite of the disembodied nature of other work, such as office jobs. Through this sensory nature of the craft process, there is an affective appeal of the process of crafting itself, which is sometimes even described as a "performance" (this performative element can include actual performances, for instance, when brewers give tours through their brewery [Thurnell-Read 2014, 19]). This fosters the identification of the craftsman with what they are doing and lead to what Paxson $(2012,72)$ has called "engaged labor" and is further enhanced by the fact that the crafter is usually in full control of the whole work process, from start to finish instead of working on one component piece of a larger product (Inkson 1987). 
Lastly, personal occupational identity is shaped and reinforced through the acquisition and practice of skills. The acquisition of skills and a process of lifelong learning involves a strong focus on problem solving, honing and specializing one's skills, which leads to both personal development (e.g., development of one's personal style) and becoming a master of one's craft (see Marchand [2016]). When it is said that skills are acquired through repeated practice, a prominent figure is an estimate of 10,000 hours of experience that are required to become an expert in one's craft (Sennett 2008, 33). It is through this continued learning that a strong sense of personal identity develops. Case studies here stress how this applied learning starts early in apprenticeship and goes far beyond learning "just" the skills of the trade: "the hallmark trait of apprenticeship: immersion in a learning environment that, in addition to facilitating technical know-how, structures the practitioner's hard-earned acquisition of social knowledge, worldviews and moral principles that denote membership and status in a trade" (Marchand 2008, 246). Apprenticeship in the crafts reflects a holistic model of education that both teaches technical skills and provides the grounding for personal formation (Marchand 2008, 245) as well as the development of a craft-centered occupational identity (Klotz, Billett, and Winther 2014). As a result, in his case study on the brewer industry, Thurnell-Read $(2014,2)$ identifies a specific brewer identity around the set of skills, competence, knowledge, and passion associated with being a brewer. These four factors have been identified in other case studies as well and are likely to generalize to all crafts. ${ }^{8}$ Note that the practice of skills is an often inherently social practice (and thus related to the interpersonal identity level) due to the tacit nature of much of a craftsman's knowledge.

Synthesizing the aspects discussed above, and using the Hackman and Oldham (1976) job characteristics model and its extension (Morgeson and Humphrey 2006), we can trace the specifics of a craftsman's occupational identity to work motivational characteristics (autonomy, task variety, task significance, task identity) and work knowledge characteristics (problemsolving, skill variety, specialization), as well as relational characteristics (social support) that are present in significant amounts in the specific work of their craft. Craftworkers thus enjoy high

\footnotetext{
${ }^{8}$ See, for instance, Chan (2014) on this character-forming exercise in baker apprentices. Something similar has been observed also in occupational identity development in grad school, where the development of skills fosters identity, but where also a social element of identity is present in the joint acquisition of "ideology" related to the subject studied (Becker and Carper 1956, 297-98).
} 
degrees of autonomy through the control of the full work process, work varied tasks within the construction of their artefact, their artefacts have significance for others, they have high task identity as they see through the construction of a whole work piece, and they get immediate task feedback through their customers when buying or commissioning their work product. Their work process is characterized by skill variety and a mix of routine tasks broken up by deviations in the work process from standard routines that require creativity and problem-solving abilities (no product is exactly the same). In this, all motivational and knowledge characteristics from the job characteristics model and its extension are reflected in the craftwork process. It is no wonder then that observers link craftwork to a strong occupational identity as well as positive affective reactions, ranging from the flow-like experience during work to higher well-being in general on the part of the craftsman. Inkson $(1987,164)$ argues that this "practice of craft gives meaning to the work, facilitates the development of skills, engrosses and delights the worker, gives pride in personal achievement, exercises and extends the creative faculty, and establishes the worker as the controlling agent in the process of work." The reward for the job as a craftsman also includes emotional aspects such as the feeling of being anchored in tangible reality and one's pride in one's own work (Sennett 2008, 33). In interviews with individuals practicing crafts (outside of their work), these aspects of meaning attached to the craft, positive feelings during the craft process, and the holisticity and intentionality of craft-making have been cited as well-being enhancing facets of working on crafted artefacts (Pöllänen 2013, 221). We thus hypothesize that: Occupational identity is higher, the higher work motivational, work knowledge and work social characteristics are $(\mathrm{H} 2)$.

More specifically, we also hypothesize that:

- Occupational identity increases in the vocational development level (from apprentice to master craftsman) (H3a); and

- Occupational identity for those doing craftwork is higher than for others such as office personnel (H3b).

Finally, given that work characteristics are shown in the literature to be positively related to both identity and job satisfaction, we will also explore the extent to which occupational identity mediates the effect of work characteristics on job satisfaction and hypothesize that: Occupational 
identity acts as mediator with regard to the relationship between work characteristics and job satisfaction (H4).

\section{DATASET, VARIABLE SELECTION, AND ECONOMETRIC STRATEGY}

\subsection{Dataset}

Within the context of an interdisciplinary research collaboration on identity, pride, and wellbeing in the skilled crafts and trades in Germany (Hemme and Blankenberg 2019), we conducted a survey amongst members of the skilled crafts and trades in Germany in the winter of 2017/2018, eliciting their attitudes toward their crafts and their satisfaction with their work, as well as their occupational identity and a range of sociodemographic variables. The survey was accessible via the internet and "The German Confederation of Skilled Crafts" (ZDH) —a lobby

group for the skilled crafts and trades, representing craft enterprises in Germany-distributed and advertised the survey to all associated chambers, organizations, and associations, which, in turn, distributed it to their member firms and informed them either via their organizational homepage or via circulars about the study and invited them to participate.

Participation in the survey took about half an hour (24 minutes on average) and respondents did not receive any payment for participation. In total, 1,930 individuals filled in the questionnaire at least partly. Calculation of a response rate is impossible due to the mode of distribution. Our sample comprises of 1,641 observations for the variables of interest. Due to nonresponse in some variables, most of our main models have around $n=750$ observations. 
Table 1: Summary Statistics for the Estimation Sample of our Main Models $(\mathrm{n}=757)$.

\begin{tabular}{|c|c|c|c|}
\hline & mean & sd & count \\
\hline Job satisfaction & 4.97 & 1.62 & 757 \\
\hline \multicolumn{4}{|l|}{ Identity } \\
\hline Identity: part of personality & 6.08 & 1.17 & 757 \\
\hline Identity: job is my calling & 5.68 & 1.39 & 757 \\
\hline Identity: proud of my job & 6.20 & 1.11 & 757 \\
\hline Identity: job is my passion & 5.71 & 1.36 & 757 \\
\hline Identity index (PCA) & 0.01 & 1.70 & 757 \\
\hline \multicolumn{4}{|l|}{ Main activity in work (percent) } \\
\hline Admin/sales & 0.09 & & 757 \\
\hline Management, no craft & 0.28 & & 757 \\
\hline Craft, with admin & 0.04 & & 757 \\
\hline Craft & 0.41 & & 757 \\
\hline Management, with craft & 0.18 & & 757 \\
\hline \multicolumn{4}{|l|}{ Vocational development stage (percent) } \\
\hline Apprentice & 0.05 & & 559 \\
\hline Journey(wo)man & 0.21 & & 559 \\
\hline Senior Journey(wo)man & 0.07 & & 559 \\
\hline Master crafts(wo)man & 0.67 & & 559 \\
\hline \multicolumn{4}{|l|}{ WDQ variables } \\
\hline Task identity: complete products/services & 5.99 & 1.21 & 757 \\
\hline Task identity: complete work process & 5.62 & 1.55 & 757 \\
\hline Task significance: work has influence on others & 5.60 & 1.28 & 757 \\
\hline Task significance: work is significant and important & 5.32 & 1.46 & 757 \\
\hline Task variety: new tasks & 5.92 & 1.17 & 757 \\
\hline Task variety: variety of tasks & 6.34 & 0.93 & 757 \\
\hline Skill variety: work requires various skills & 6.32 & 0.84 & 757 \\
\hline Specialization: work requires specialized skills & 6.04 & 1.07 & 757 \\
\hline Problem solving: task with no clear solutions & 5.56 & 1.43 & 757 \\
\hline Problem solving: creativity is important for my work & 5.75 & 1.36 & 757 \\
\hline Social support: meet new people at work & 6.01 & 1.22 & 757 \\
\hline Social support: colleagues are also friends & 4.46 & 1.66 & 757 \\
\hline Autonomy: can make many decisions on my own & 6.08 & 1.16 & 757 \\
\hline Autonomy: abilities allow different approaches & 6.07 & 1.13 & 757 \\
\hline \multicolumn{4}{|l|}{ Control variables } \\
\hline Net income, monthly & 2712.29 & 3648.18 & 757 \\
\hline Income (IHS transformed) & 8.36 & 0.78 & 757 \\
\hline Age & 43.15 & 12.59 & 757 \\
\hline $\mathrm{Age}^{2}$ & 20.20 & 10.97 & 757 \\
\hline Gender: female $(0 / 1)$ & 0.17 & & 757 \\
\hline Hours worked & 48.43 & 13.30 & 757 \\
\hline Self-employed $(0 / 1)$ & 0.54 & & 757 \\
\hline \multicolumn{4}{|l|}{ Full-time (percent) } \\
\hline Full-time & 0.94 & & 757 \\
\hline Part-time & 0.06 & & 757 \\
\hline \multicolumn{4}{|l|}{ Firm size (percent) } \\
\hline Solo & 0.07 & & 757 \\
\hline 2 to 20 & 0.67 & & 757 \\
\hline 21 to 100 & 0.17 & & 757 \\
\hline $101+$ & 0.08 & & 757 \\
\hline \multicolumn{4}{|l|}{ Education, CASMIN Scale (percent) } \\
\hline Primary & 0.14 & & 757 \\
\hline Secondary & 0.69 & & 757 \\
\hline Tertiary & 0.17 & & 757 \\
\hline \multicolumn{4}{|l|}{ Big Five } \\
\hline Big five: extraversion & 15.28 & 3.31 & 757 \\
\hline Big five: conscientiousness & 17.62 & 2.28 & 757 \\
\hline Big five: agreeableness & 15.41 & 2.58 & 757 \\
\hline Big five: openness & 15.99 & 3.00 & 757 \\
\hline Big five: neuroticism & 11.52 & 3.44 & 757 \\
\hline Observations & 757 & & \\
\hline
\end{tabular}

Note: Full descriptive statistics for the entire dataset presented in table A2.

Source: Own data. 


\subsection{Variable Descriptions}

Descriptive statistics of the sample are provided in table 1. In the following, we restrict our attention to the sample of 757 respondents who make up our main analyses later ("main estimation sample"). In line with the exposition above, our main variables of interest are job satisfaction and occupational identity of our respondents.

We measure job satisfaction via the question: "How dissatisfied or satisfied, overall, are you with your job?" This question has a long tradition in research on employee well-being (Locke 1969; Freeman 1978; Warr 1992) and is widely used today (see Judge and Klinger 2007; Fisher 2010). Respondents are asked to answer the question on a seven-point Likert scale (which ranges from 1 $=$ "not satisfied at all" up to $7=$ "completely satisfied"). Validity and reliability of these measures has long been established (Lucas 2018; Krueger and Schkade 2008). The mean value for job satisfaction over all respondents in our dataset is 4.97 , with a standard deviation of 1.62 . It has to be noted that this measure mostly taps into cognitive, not affective, evaluation of the individual (pace the definition in Locke [1969]) and that single-item measures are somewhat less reliable than multi-item measures. Figure 1, left panel, shows the distribution of the job satisfaction variable, overlaid with a normal distribution, indicating a somewhat left-skewed distribution.

\section{Figure 1: Histogram of Percentage of Answers to Job Satisfaction Question Response Categories Overlaid with a Normal Kernel Density Plot (left side), Scatterplot that Plots the Identity Index against Job Satisfaction Response (right side)}
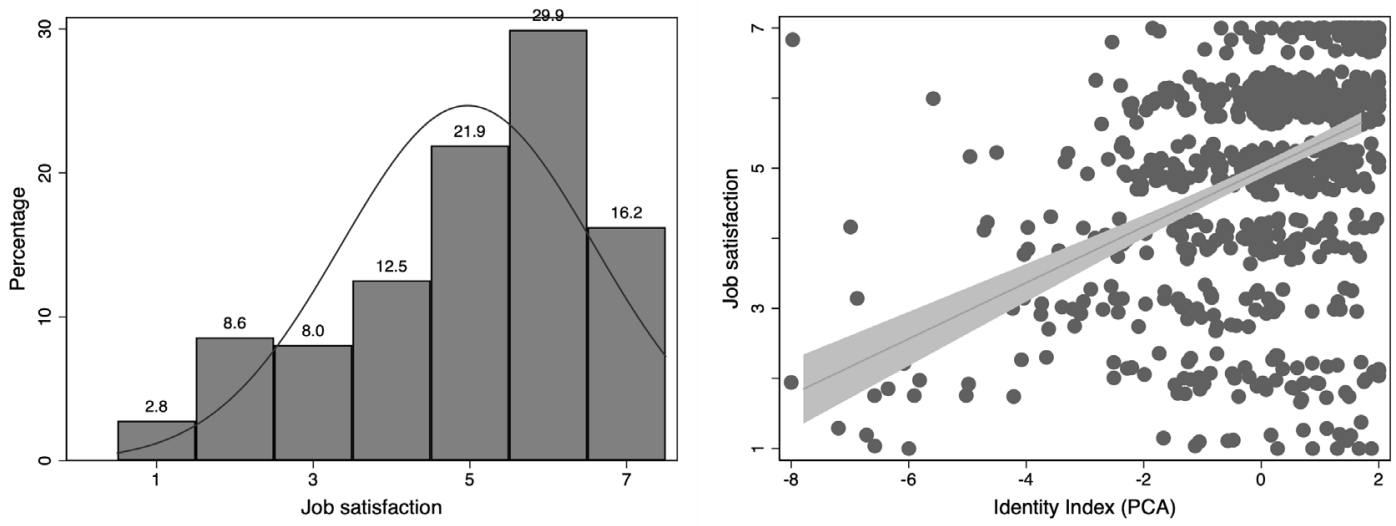

Note: The scatter plot is overlaid with the regression line for the relationship between job satisfaction and identity index variable and 95 percent confidence interval. Both plots display data from the estimation sample for our main models $(\mathrm{n}=757)$.

Source: Own data. 
Measuring occupational identity is not as straightforward. The literature on occupational identity is "fragmented" and "haphazard" (Miscenko and Day 2016, 216) and no consensus exists on a singular definition of occupational identity, let alone empirical constructs to measure it. While a widely used scale of "organizational identification" (Mael and Ashforth 1992; Haslam 2004: appx 1) taps into an individual's social identity as member of a firm or organization (it contains statements such as "When someone criticizes [Organization X], it feels like a personal insult," with which respondents can agree/disagree), it neglects many of the aspects of occupational identity discussed above. A different, well-known scale of "vocational identity" (Holland, Johnston, and Asama 1993) is mostly centered around identity before entering a profession (i.e., in adolescence). Recent attempts at measuring occupational identity come from Gupta, Chong, and Leong (2015), Klotz, Billett, and Winther (2014), and Berg (2017), the latter of which similarly notes that there is no instrument for recording the developed professional identity after professional socialization and provides a 15-item questionnaire containing items such as "My job enriches my life" or "My job suits me."

Based on our literature review above, we measure occupational identity via four questions, to which respondents are asked to indicate their agreement on a seven-point Likert scale (which ranges from 1 = "do not agree at all" up to 7 = "completely agree"). As detailed above, identity can be thought of as being a core part of an individual's concept of a person. We elicit this via the statement: "My job as a crafts(wo)man is a significant part of my personality" (mean 6.08, s.d. 1.17; this question is also used in Berg [2017], Carson and Bedeian [1994], and Klotz, Billett, and Winther 2014). We also ask individuals to what extent they consider their work their "calling": "My profession is my calling" (mean 5.68, s.d. 1.39). While there is consensus that this is closely related to occupational identity (Dobrow 2004; Hirschi 2011; Berg 2017), there is disagreement whether a calling should be seen as a separate construct. We follow Berg here in maintaining that a "calling" should be conceived of as an extremely strong occupational identity, seeing one's job as a strong reflection of oneself, and/or a deep part of an individual's overall self-concept (Berg 2017). Both questions tap into the cognitive aspects of one's identity, namely self-definition and importance of the job for a person's self-concept (Ashforth, Harrison, and Corley 2008, 330).

But occupational identity also has a strong affective part, which we tap into by asking about individuals' pride in and passion for their work. With regard to pride, which can be considered to 
be a psychological state entailed through high occupational identity (Haslam 2004, 77-78), we ask individuals not about their pride regarding their organization, but regarding their work and job in general (Klotz, Billett, and Winther 2014; Blau 1985; Van Dick and Stegmann 2015, 53): "I am proud of my job" (mean 6.20, s.d. 1.11; this adapts a question relevant for organizational identification and is also part of the scale proposed in Berg [2017]). With regard to passion, we ask respondents about their agreement with the following statement: "My profession is my passion" (mean 5.71, s.d. 1.36).

Based on these questions, we have created an occupational identity index via principal component analysis ([PCA] centered with zero mean and s.d. 1.70; Kaiser-Meyer-Olkin measure $[\mathrm{KMO}]$, .77). The internal consistency of such an index measured via Cronbach's $\alpha$ is .88 (compare this to the Mael/Asforth scale having $\alpha$ 's greater than .80, see Haslam [2004, 273] or Berg's measure with an alpha .93 for a 15 -item scale). To see whether the calling variable would tap into a different construct, we conducted a confirmatory factor analysis, hypothesizing that all four items would load onto the same factor. Eigenvalues greater than one for the first factor and close to zero for any further factors and a scree plot leveling off strongly with the second factor confirm that our theory-guided idea of a one factor structure is empirically plausible (see the scree plot depicted as figure A1). Our measure is mostly similar to the "vocational identity" measure proposed by Klotz, Billett, and Winther $(2014,12)$, but has slightly better internal consistency. Figure 1, right panel, shows a scatter plot of the identity index in relation to individuals' job satisfaction overlaid with a line of best fit (indicating a positive linear relationship between identity and job satisfaction). The raw data supports our first hypothesis (H1).

As discussed above, central independent variables cover work characteristics, which can be divided into motivational characteristics (amongst them task identity, task significance, task variety, task autonomy), work knowledge characteristics (problem solving, skill variety, specialization), and social characteristics (e.g., social support; see Hackman and Oldham [1976] and Morgeson and Humphrey [2006]). We have asked respondents a number of questions from the well-known "work design questionnaire" (WDQ) (Morgeson and Humphrey 2006; Humphrey, Nahrgang, and Morgeson 2007; Stegmann et al. 2010) to tap into these characteristics (all questions below are direct translations or adaptations from the WDQ). We asked all 
respondents to answer the work characteristic questions on a seven-point Likert scale (which ranges from 1 = "do not agree at all" up to 7 = "completely agree"; see Table 1).

"Task identity" reflects the extent to which one's job tasks lead to an entire piece of work, i.e., how holistic one's work process is. We measure this via the following items: (1) "The job involves completing a piece of work that has an obvious beginning and end" and (2) "The job is arranged so that I can do an entire piece of work from beginning to end." "Task significance" relates to how significant one's work is in general and for other people, and we elicit this via the following two items: (1) "The result of my work has a great influence on other people" and (2) "My work is significant and important in a larger context." "Task variety" reflects the extent to which one's work is not monotonous and is elicited via the two items: (1) "The job involves doing a number of different things/performance of a wide range of tasks" and (2) "The job involves performing a variety of tasks." "Task autonomy" describes decision-making autonomy and work method or work scheduling choices the individual has in carrying out their work. We measure this via agreement to the items: (1) "In my work I can often choose between different approaches based on my abilities" and one item for decision-making autonomy, namely (2) "The job allows me to make a lot of decisions on my own."

Turning to work knowledge characteristics, we focus on problem solving, skill variety, and specialization. Based on Morgeson and Humphrey (2006), we use the following two items for problem-solving: (1) "In my work I have to solve tasks for which there is no clear solution" and (2) "Creativity is very important for my work." Skill variety comprises the use of multiple skills that are required to complete the work, which we measure by agreement with the item "Work requires various skills." Specialization is measured via the item "Work requires specialized skills." 
Figure 2: Average Job Satisfaction and Average Identity Level for the Four Individual Identity Items and the Composite Identity Index (computed via principal component analysis), Split by Type of Work

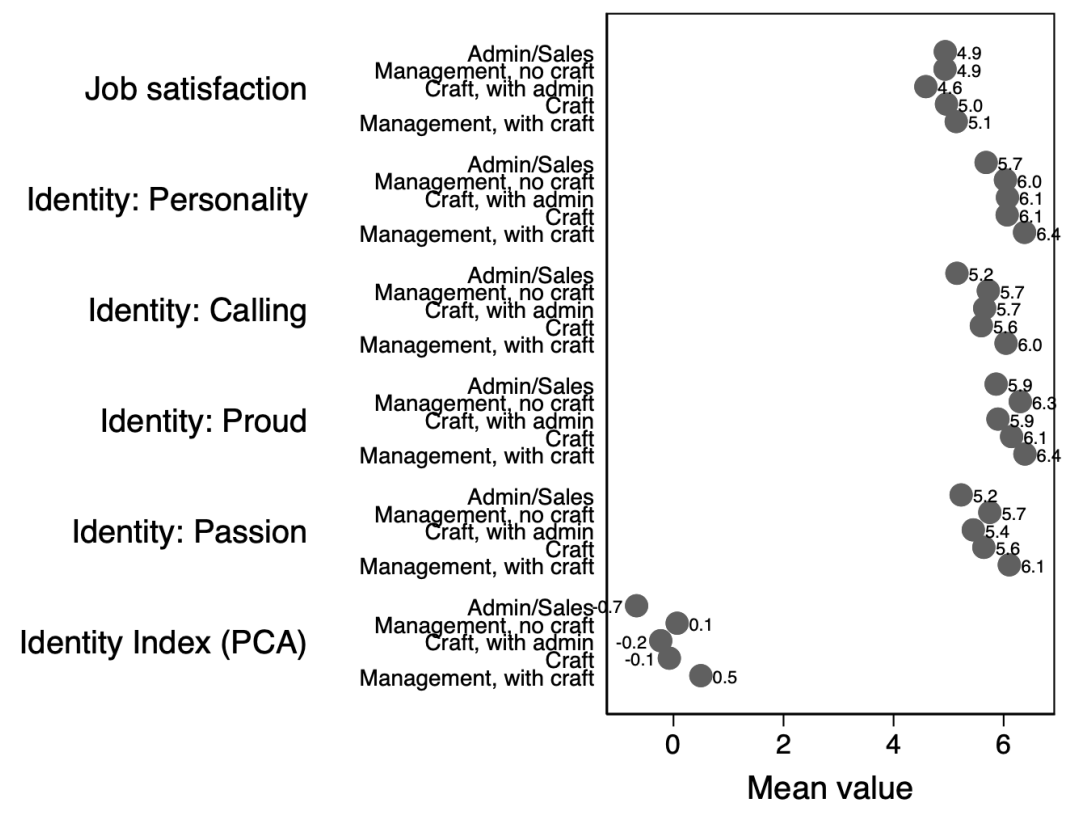

Note: The individual items range from 1 to 7 in their answers, whereas the composite index is artificially centered around 0.01 with an s.d. of 1.70. Plot displays data from the estimation sample for our main models $(\mathrm{n}=757)$. Source: Own data

For social characteristics (Morgeson and Humphrey 2006, 1338), we use two items about workplace social support, namely (1) "I have the chance in my job to get to know other people" and (2) "I have the opportunity to develop close friendships in my job."

In addition to work characteristics, we know whether respondents are apprentices (5 percent), journey(wo)men (21 percent), senior journey(wo)men (7 percent), or master crafts(wo)men (67 percent; we call this their "vocational development stage") and we have also elicited from them their main work role ("main activity in work"), where they could check multiple items from the list of "being craftsman," "doing sales/distribution," "doing administration," and "having a management role in the firm." We have grouped answers into the following categories: (1) individuals only doing administration and/or sales (office position, 9 percent), (2) individuals leading a company without doing any crafting themselves ("Management, no craft," 28 percent), (3) craftsmen who also do administrative work (4 percent), (4) pure craftsmen (no office work or management, 41 percent), and (5) craftsmen who are also their own boss or have a management role (and hence may also do some office work, 18 percent). Figure 2 shows the mean identity and 
job satisfaction values split by main type of activity respondents do in their work. A first look here shows that identity is highest for those who either craft or lead a firm (with those doing both having the highest levels of identity). Job satisfaction is highest for craftsmen and those craftsmen who are also in charge of their own firm (which supports hypothesis $3 b$ ). Interestingly, craftsmen having to do office work show the lowest job satisfaction. Welch's t-tests comparing pure craftsmen and those who run their own firm with all others show significantly higher identity $(\mathrm{d}=.22, \mathrm{t}(688.978)=1.74, \mathrm{p}<.10)$, but the job satisfaction premium is not statistically distinguishable $(\mathrm{d}=.12, \mathrm{t}(692.109)=0.98, \mathrm{p}=.33)$.

Figure 3 shows occupational identity and job satisfaction disaggregated by vocational development stage. In support of hypothesis (3a), we can see that identity and job satisfaction increase with professional development and are highest for master craftsmen: Welch's t-tests comparing master craftsmen with all others show significant differences for both job satisfaction $(\mathrm{d}=.32, \mathrm{t}(355.368)=2.17, \mathrm{p}<.05)$ and identity $(\mathrm{d}=.63, \mathrm{t}(296.592)=3.98, \mathrm{p}<.001)$.

To avoid confounding, we add control variables to our analysis that are informed by previous research and theorizing on job satisfaction and occupational identity (e.g., Judge and Klinger 2007; Fisher 2010): demographic and socioeconomic variables used in our analysis include age, $\operatorname{age}^{2}$ (with an average age of 43 years), monthly income (mean value of $€ 2,712.29$ ), and gender (17 percent are female). We also have information about the hours worked (48.43), firm size (67 percent in small firms of 2-20 persons), and whether the respondent is self-employed (54 percent are). We further use information about the educational level (using the well-established CASMIN scale of educational achievement: primary, 14 percent; secondary, 69 percent; and tertiary, 17 percent), and personality traits (extraversion, agreeableness, neuroticism, openness, conscientiousness). 
Figure 3: Average Job Satisfaction and Average Identity Level for the Four Individual Identity Items and the Composite Identity Index (computed via principal component analysis) Split by Vocational Development Stage

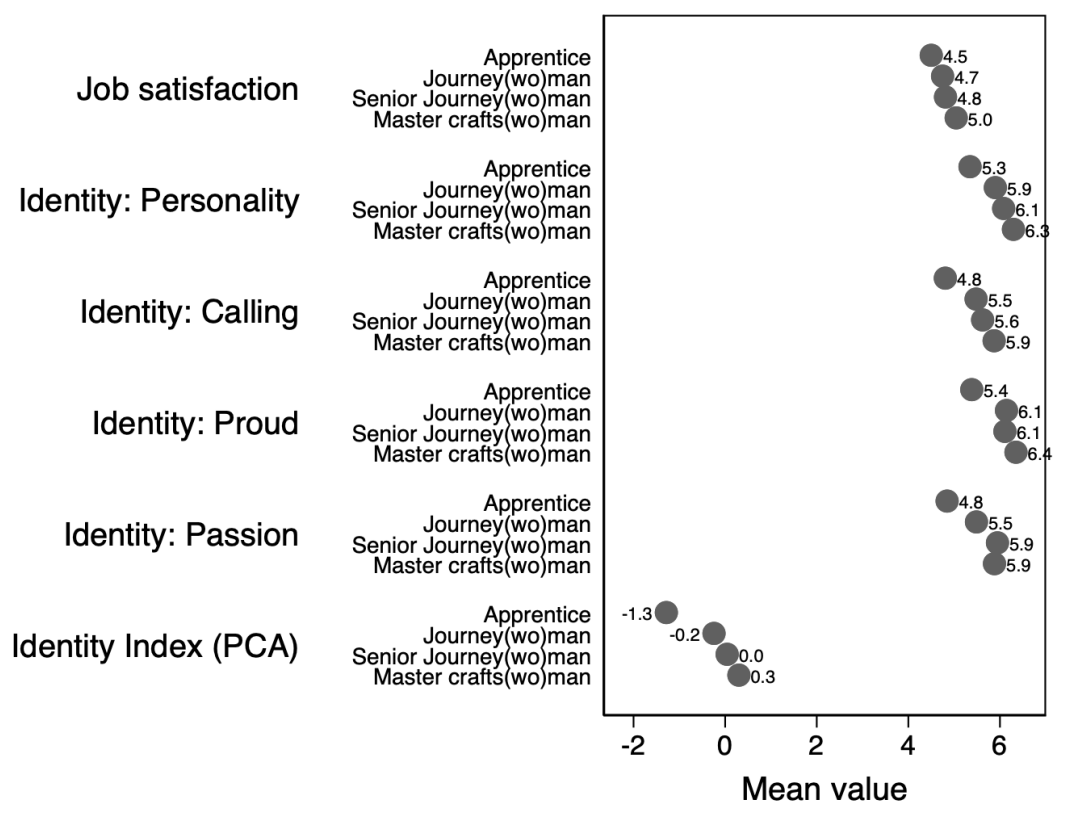

Note: The individual items range from 1 to 7 in their answers, whereas the composite index is artificially centered around 0.01 with an s.d. of 1.70 . Plot displays data from the estimation sample for our main models $(n=757)$.

Source: Own data.

Table A2 depicts bivariate (Pearson) correlations. We can find no evidence for severe multicollinearity - the highest bivariate correlation is between the two task variety measures $(\mathrm{r}=$ $0.66, \mathrm{p}<0.001$ ). We see that job satisfaction is positively related to identity (with $\mathrm{r}=0.42, \mathrm{p}<$ 0.001 ) and to all work characteristics. We have also computed variance inflation factors (VIFs) for our main models and all VIFs are below 2 (with the expected exception of age and hours worked and their respective squared terms).

\subsection{Representativeness of the Sample}

To get a sense of the representativeness of our sample, we can compare sociodemographic information of our sample with a representative German household panel data set (SOEP) and with other data on crafts(wo)men in Germany (ifh Goettingen 2017). Using the SOEP's (weighted) 2017 wave, we find our sample similar with regard to gender (16 percent female versus 17 percent in our sample) and average age (both 43 years). But we oversample more highly educated individuals (in our sample: primary education, 43 percent versus 14 percent; 
secondary education, 52 percent versus 69 percent; tertiary education, 5 percent versus 17 percent). We also oversample master craftsmen (14 percent of all craftsmen in Germany in 2013 versus 67 percent in our sample) and the self-employed in the crafts (10 percent versus 54 percent in our sample), whereas we slightly undersample apprentices ( 7 percent versus 5 percent in our sample). Accordingly, our sample also outearns the general population of craftsmen on average (net labor income $€ 1,679$ versus $€ 2,720$ in our sample). These differences in our sample from the population of German craftsmen should be kept in mind when interpreting our results.

\subsection{Econometric Strategy}

We use multivariate regression analysis to analyze how job satisfaction is influenced by occupational identity and its interplay with work characteristics (see table 2), and estimate

$$
J S_{i}=\alpha_{i}+\beta_{i} W+\gamma_{i} E\left(+\delta_{i} I D+\zeta_{i} W D Q\right)+\eta_{i} Z+\epsilon_{i}
$$

where $\alpha$ denotes the constant, and $\beta$ and $\gamma$ are the coefficients for wage and effort variables (in the simple model). The focus of our paper is on $\delta$, the coefficient of the occupational identity index variable (ID), as well as $\zeta$, the coefficient vector of work characteristics (WDQ). $\eta$ refers to the vector of coefficients of control variables $(Z)$ for each individual (i), and $\epsilon_{i}$ is the error term.

Second, we are interested in how these work characteristics, as well as type of work and work position, impact on occupational identity (see table 3), and estimate the following regression equation:

$$
I D_{i}=\alpha_{i}+\beta_{i} W D Q\left(+\theta_{i} A C T+\kappa_{i} P O S\right)+\eta_{i} Z+\epsilon_{i}
$$

where $\theta$ and $\kappa$ in this model refer to the coefficients of the main work activity variable (ACT) and vocational position variable (POS), respectively. 
We use standard ordinary least-squares (OLS) regressions with heteroscedasticity-robust standard errors, which we additionally cluster at the level of German postal codes. ${ }^{9}$ As the regressions with job satisfaction have a dependent variable on an ordinal scale, we have also run ordered probit regressions to account for this deviation from OLS assumptions, but results are very similar to our main analysis (see table A7). Consensus in the literature has emerged that a linear estimator can be usefully employed with satisfaction variables and controlling for individualspecific types of heterogeneity is much more important than using ordered choice models (Ferreri-Carbonell and Frijters 2004). Our results are also robust to narrowing down our model to only full-time workers (see table A3 and table A4). ${ }^{10}$

\section{RESULTS}

\subsection{Job Satisfaction, Occupational Identity, and Work Characteristics}

To analyze the relationship between job satisfaction and occupational identity, we start with a typical job satisfaction regression and a set of control variables (table 2, column $1, \mathrm{n}=757$ ), where income and effort variables are considered to be main determinants of job satisfaction in accordance with the standard model presented in equation (1). While our effort variables are not significantly related with job satisfaction, income has a small and barely statistically significant association $(b=0.16, p<.10)$. In support of hypothesis $(1)$, when we now add our occupational identity index variable (column 2), we find a strongly positive association between job satisfaction and identity for our sample $(b=0.34, p<.001)$. Considering the arbitrary scale for the identity index, the above coefficient translates into a $0.34 * 1.70=0.58$-unit increase in job satisfaction for a 1 s.d. increase in occupational identity, which is quite substantial. Comparison of effect sizes with the few studies in the literature measuring broader occupational identity constructs is hampered by the fact that those either do not provide more than zero-order correlations or use different constructs for both job satisfaction and identity. Nevertheless, we

\footnotetext{
${ }^{9}$ Density plots show that regression residuals are approximately normal, but standard normal and normal Q-Q plots show some skew at the extremes of the residual distribution. A Shapiro-Wilk test rejects normality. Removing six influential outliers ameliorates this but does not strongly change main results presented in the manuscript. BreuschPagan test and Cameron and Trivedi's decomposition of IM-test suggest presence of heteroscedasticity.

${ }^{10}$ Results also do not substantially change when estimating our models using tobit regressions, see table A5 and table A6.
} 
note that Berg (2017) finds a raw correlation between job satisfaction and identity of $r=.65$ (p. 175), which is stronger than our zero-order correlation reported above $(\mathrm{r}=.42)$. Riketta and Van Dick (2005) provide correlations of similar magnitude for job satisfaction and organizational $(\mathrm{r}=$ $.54)$ and workgroup identity $(r=.46)$ in their meta-analysis $(p .501) .{ }^{11}$

${ }^{11}$ In work not pursued here in more detail, we also find identity strongly positively related to the difference between hours a crafter wants to work and has to work: strong identity makes crafters want to work more. High occupational identity also leads to significantly lower levels in turnover intention. 
Table 2: OLS Regressions with Job Satisfaction as Dependent Variable

\begin{tabular}{|c|c|c|c|c|c|c|c|c|}
\hline \multirow{2}{*}{$\begin{array}{l}\text { Identity (Independent variable) } \\
\text { Identity index (PCA) }\end{array}$} & \multicolumn{2}{|c|}{$\begin{array}{c}(1) \\
\text { Standard }\end{array}$} & \multicolumn{2}{|c|}{$\begin{array}{c}(2) \\
\text { ID Index }\end{array}$} & \multicolumn{2}{|c|}{$\begin{array}{c}(3) \\
\text { WORK CHAR. }\end{array}$} & \multicolumn{2}{|c|}{$\begin{array}{c}(4) \\
\text { WORK CHAR. + ID }\end{array}$} \\
\hline & & & $0.34^{* * *}$ & $(9.62)$ & & & $0.29^{* * *}$ & (7.07) \\
\hline $\begin{array}{l}\text { WDQ (Independent variables) } \\
\text { Task identity: complete products/services } \\
\text { Task identity: complete work process } \\
\text { Task significance: work has influence on others } \\
\text { Task significance: work is significant and important } \\
\text { Task variety: new tasks } \\
\text { Task variety: variety of tasks } \\
\text { Skill variety: work requires various skills } \\
\text { Specialization: work requires specialized skills } \\
\text { Problem-solving: task with no clear solutions } \\
\text { Problem-solving: creativity is important for my work } \\
\text { Social support: meet new people at work } \\
\text { Social support: colleagues are also friends } \\
\text { Autonomy: can make many decisions on my own } \\
\text { Autonomy: abilities allow different approaches }\end{array}$ & & & & & $\begin{array}{c}-0.02 \\
0.09^{*} \\
0.17^{* *} \\
0.01 \\
0.19^{* *} \\
-0.04 \\
0.04 \\
-0.03 \\
-0.07 \\
-0.01 \\
-0.08 \\
0.07^{*} \\
0.16^{*} \\
0.01\end{array}$ & $\begin{array}{c}(-0.30) \\
(2.31) \\
(2.92) \\
(0.21) \\
(2.83) \\
(-0.54) \\
(0.41) \\
(-0.46) \\
(-1.59) \\
(-0.19) \\
(-1.54) \\
(2.11) \\
(2.36) \\
(0.07)\end{array}$ & $\begin{array}{c}-0.03 \\
0.08^{*} \\
0.17^{* *} \\
-0.05 \\
0.13^{+} \\
-0.04 \\
-0.03 \\
-0.01 \\
-0.06 \\
-0.02 \\
-0.10^{*} \\
0.02 \\
0.14^{*} \\
-0.00\end{array}$ & $\begin{array}{l}(-0.54) \\
(2.29) \\
(3.24) \\
(-1.03) \\
(1.95) \\
(-0.57) \\
(-0.32) \\
(-0.20) \\
(-1.25) \\
(-0.33) \\
(-2.09) \\
(0.56) \\
(2.14) \\
(-0.05)\end{array}$ \\
\hline $\begin{array}{l}\text { Simple model: Wage, effort (Indep.Variables) } \\
\text { Income (IHS transformed) } \\
\text { Part-time }(y / n) \\
\text { Hours worked } \\
\text { Hours worked x Hours worked }\end{array}$ & $\begin{array}{l}0.16^{+} \\
-0.35 \\
-0.01 \\
-0.00\end{array}$ & $\begin{array}{l}(1.91) \\
(-1.18) \\
(-0.27) \\
(-0.29)\end{array}$ & $\begin{array}{c}0.09 \\
-0.19 \\
-0.01 \\
0.00\end{array}$ & $\begin{array}{c}(1.21) \\
(-0.59) \\
(-0.59) \\
(0.01)\end{array}$ & $\begin{array}{l}0.14^{+} \\
-0.44 \\
-0.01 \\
-0.00\end{array}$ & $\begin{array}{l}(1.87) \\
(-1.38) \\
(-0.49) \\
(-0.04)\end{array}$ & $\begin{array}{c}0.10 \\
-0.32 \\
-0.01 \\
0.00\end{array}$ & $\begin{array}{c}(1.43) \\
(-0.96) \\
(-0.58) \\
(0.02)\end{array}$ \\
\hline $\begin{array}{l}\text { Control variables } \\
\text { Gender: female }(0 / 1) \\
\text { Age } \\
\text { Age }^{2} \\
\text { Self-employed }(0 / 1)\end{array}$ & $\begin{array}{c}0.63^{* * *} \\
-0.11^{* * *} \\
0.13^{* * *} \\
0.49^{* *}\end{array}$ & $\begin{array}{l}(4.49) \\
(-3.94) \\
(4.23) \\
(3.06)\end{array}$ & $\begin{array}{c}0.54^{* * *} \\
-0.09^{* * *} \\
0.11^{* * *} \\
0.35^{*}\end{array}$ & $\begin{array}{c}(3.98) \\
(-3.62) \\
(3.90) \\
(2.34)\end{array}$ & $\begin{array}{c}0.60^{* * *} \\
-0.10^{* * *} \\
0.12^{* * *} \\
0.31^{+}\end{array}$ & $\begin{array}{l}(4.28) \\
(-3.62) \\
(3.88) \\
(1.95)\end{array}$ & $\begin{array}{c}0.50^{* * *} \\
-0.09^{* * *} \\
0.11^{* * *} \\
0.28^{+}\end{array}$ & $\begin{array}{l}(3.61) \\
(-3.41) \\
(3.69) \\
(1.83)\end{array}$ \\
\hline $\begin{array}{l}\text { Firm size (base: } 2 \text { to } 20) \text { ) } \\
\text { Solo } \\
21 \text { to } 100 \\
101+\end{array}$ & $\begin{array}{r}0.20 \\
-0.01 \\
0.16\end{array}$ & $\begin{array}{l}(0.97) \\
(-0.07) \\
(0.75)\end{array}$ & $\begin{array}{l}0.19 \\
0.05 \\
0.16\end{array}$ & $\begin{array}{l}(0.91) \\
(0.36) \\
(0.80)\end{array}$ & $\begin{array}{l}0.09 \\
0.04 \\
0.28\end{array}$ & $\begin{array}{l}(0.44) \\
(0.29) \\
(1.31)\end{array}$ & $\begin{array}{l}0.14 \\
0.08 \\
0.25\end{array}$ & $\begin{array}{l}(0.66) \\
(0.58) \\
(1.25)\end{array}$ \\
\hline $\begin{array}{l}\text { Education (CASMIN scale, base: Secondary) } \\
\text { Primary } \\
\text { Tertiary }\end{array}$ & $\begin{array}{c}-0.41^{*} \\
-0.06\end{array}$ & $\begin{array}{l}(-2.40) \\
(-0.37)\end{array}$ & $\begin{array}{c}-0.33^{*} \\
0.01\end{array}$ & $\begin{array}{c}(-2.10) \\
(0.10)\end{array}$ & $\begin{array}{c}-0.41^{*} \\
-0.06\end{array}$ & $\begin{array}{l}(-2.53) \\
(-0.41)\end{array}$ & $\begin{array}{c}-0.36^{*} \\
0.00\end{array}$ & $\begin{array}{r}(-2.29) \\
(0.03)\end{array}$ \\
\hline $\begin{array}{l}\text { Living (base: Village) } \\
\text { Small town } \\
\text { City } \\
\text { Large city }\end{array}$ & $\begin{array}{l}-0.30^{*} \\
-0.17 \\
-0.08\end{array}$ & $\begin{array}{l}(-2.01) \\
(-1.17) \\
(-0.41)\end{array}$ & $\begin{array}{c}-0.19 \\
-0.11 \\
0.03\end{array}$ & $\begin{array}{l}(-1.31) \\
(-0.86) \\
(0.15)\end{array}$ & $\begin{array}{c}-0.30^{*} \\
-0.00 \\
0.02\end{array}$ & $\begin{array}{c}(-2.03) \\
(-0.01) \\
(0.10)\end{array}$ & $\begin{array}{c}-0.22 \\
-0.02 \\
0.07\end{array}$ & $\begin{array}{c}(-1.49) \\
(-0.14) \\
(0.38)\end{array}$ \\
\hline $\begin{array}{l}\text { Personality traits } \\
\text { Big five: extraversion } \\
\text { Big five: conscientiousness } \\
\text { Big five: agreeableness } \\
\text { Big five: openness } \\
\text { Big five: neuroticism }\end{array}$ & $\begin{array}{l}0.05^{* *} \\
0.05^{+} \\
0.03 \\
-0.01 \\
-0.11^{* * *}\end{array}$ & $\begin{array}{l}(2.81) \\
(1.79) \\
(1.26) \\
(-0.41) \\
(-6.56)\end{array}$ & $\begin{array}{c}0.03^{*} \\
-0.00 \\
0.02 \\
-0.04^{*} \\
-0.10^{* * *}\end{array}$ & $\begin{array}{l}(2.01) \\
(-0.09) \\
(0.83) \\
(-2.31) \\
(-6.27)\end{array}$ & $\begin{array}{c}0.03 \\
0.01 \\
0.02 \\
-0.02 \\
-0.10 * * *\end{array}$ & $\begin{array}{l}(1.53) \\
(0.52) \\
(0.79) \\
(-0.96) \\
(-5.63)\end{array}$ & $\begin{array}{c}0.03 \\
-0.01 \\
0.02 \\
-0.04^{+} \\
-0.09^{* * *}\end{array}$ & $\begin{array}{r}(1.54) \\
(-0.36) \\
(0.71) \\
(-1.78) \\
(-5.70)\end{array}$ \\
\hline Constant & $5.33 * * *$ & (4.40) & $7.33^{* * *}$ & (6.37) & $3.91 * * *$ & (3.37) & $6.29^{* * *}$ & (5.38) \\
\hline $\begin{array}{l}\text { Observations } \\
\text { F } \\
\text { Degrees of freedom } \\
\text { Adj. } R^{2}\end{array}$ & $\begin{array}{r}757 \\
9.81 \\
653 \\
0.15\end{array}$ & & $\begin{array}{c}757 \\
14.56 \\
653 \\
0.25\end{array}$ & & $\begin{array}{c}757 \\
10.20 \\
653 \\
0.22\end{array}$ & & $\begin{array}{c}757 \\
11.61 \\
653 \\
0.28\end{array}$ & \\
\hline
\end{tabular}

Notes: Model (1) estimates the relationship between job satisfaction and income and work effort. Model (2) adds the occupational identity variable as main explanatory variable. Model (3) shows work characteristics as explanatory variables and model (4) presents the relationship between job satisfaction and occupational identity while also controlling for work characteristics. Heteroscedasticity-robust standard errors are clustered on the postal code level. Estimation sample kept identical for all models. Unweighted data.

Source: Own data. 
In addition, it should be noted that our income variable now turns insignificant after adding the occupational identity variable, a pattern that is visible throughout all further models, i.e., income is not significantly associated with job satisfaction and identity or only barely so in all models, whereas our main explanatory variables as proposed by the modified Akerlof and Kranton model, i.e., occupational identity and work characteristics, are robustly related to our dependent variables. Note also that the explanatory power of the extended model increases from an adjusted $\mathrm{R}^{2}$ of .15 to .25 when including identity, and .28 when including both occupational identity and work characteristics. This shows that equation (2) is an empirically more useful characterization of individuals' work well-being and supports our contention that occupational identity and work characteristics are substantively important explanatory variables for job satisfaction.

Columns (3) and (4) now also add work characteristics to our regression model, first without including our identity index variable, then including it. Column (3) shows that not all work characteristics variables in our sample are individually correlated with job satisfaction (but an Ftest for joint significance of all WDQ is strongly significant, $\mathrm{F}(14,653)=5.96, \mathrm{p}<.001)$. In line with our theoretical discussion of the peculiarities in the skilled crafts and trades, we find that task identity (complete work process, $\mathrm{b}=0.09, \mathrm{p}<.05$ ), task significance (influence on others, $\mathrm{b}$ $=0.17, \mathrm{p}<.01$ ), task variety (new tasks, $\mathrm{b}=0.19, \mathrm{p}<.01$ ), task autonomy (can make decisions, $\mathrm{b}$ $=0.16, \mathrm{p}<.01$ ), and social support (colleagues are friends, $\mathrm{b}=0.07, \mathrm{p}<.05$ ) are positively related to job satisfaction. These positive associations confirm theoretical expectations and are similar to empirical results not specifically focused on the skilled crafts and trades (Humphrey, Nahrgang, and Morgeson 2007; Wegge et al. 2006), which attests to the generalizability of our findings beyond the skilled crafts and trades. Especially autonomy and social support have been characterized as strong predictors of job satisfaction in previous meta-analytic research (Humphrey, Nahrgang, and Morgeson 1348), which is explained with universal needs for autonomy and relatedness (e.g., Deci and Ryan 2000). 
Table 3: OLS Regressions with Occupational Identity Index as Dependent Variable

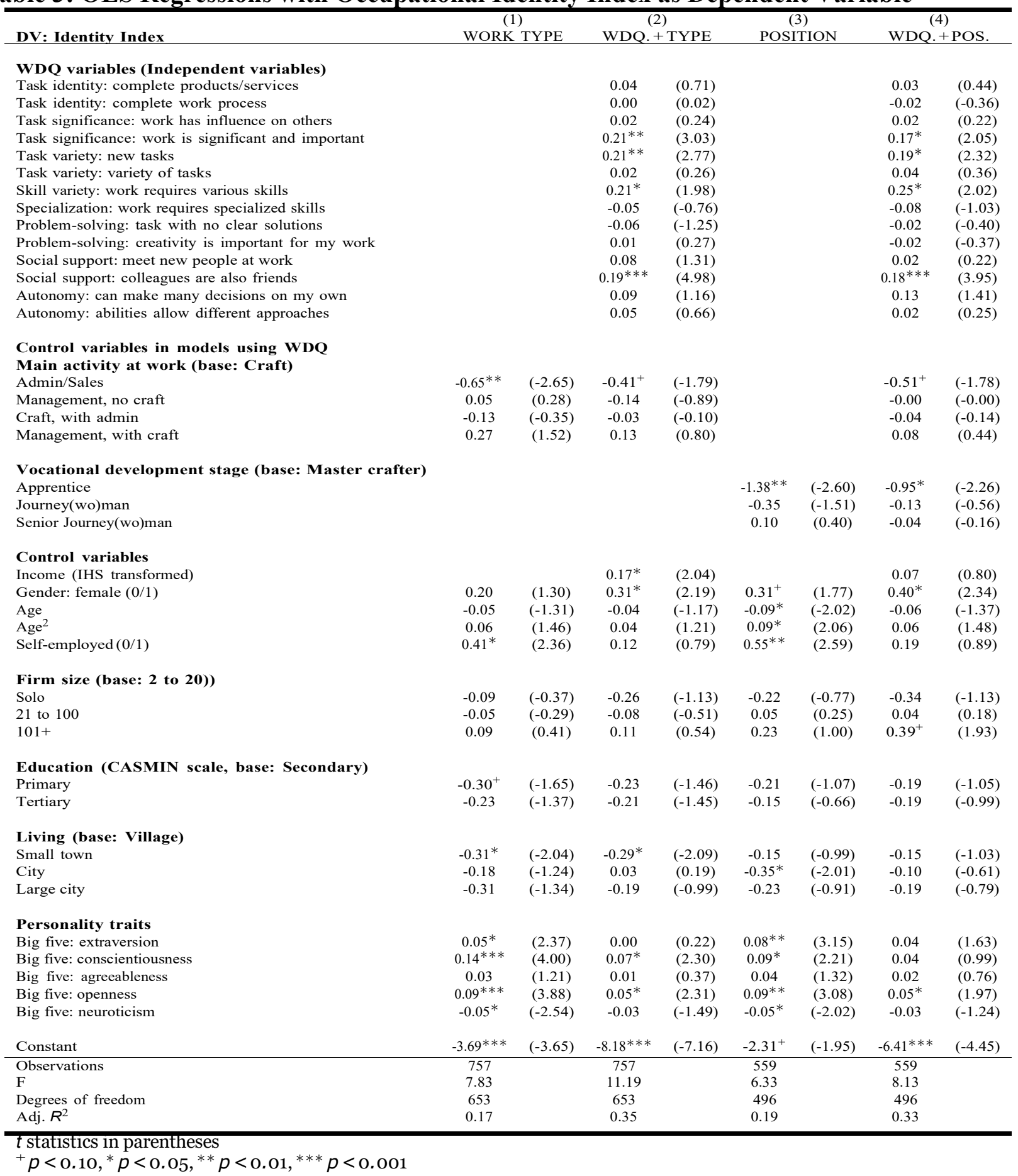

Notes: Model (1) analyzes the relationship between occupational identity and main activity at work, model (2) between occupational identity and work characteristics. Models (3) and (4) repeat this analysis with focus on the relationship between occupational identity and vocational position. Heteroscedasticity-robust standard errors clustered on the postal code level. Estimation sample kept identical in models (1) and (2) but is lower for models (3) and (4) due to missing data concerning occupational position. Unweighted data.

Source: Own data. 
As discussed in the literature section, work characteristics are likely to influence occupational identity and hence we would expect the latter to mediate the former. To our knowledge, there is not yet any research exploring the extent to which occupational identity mediates the association between work characteristics and job satisfaction. ${ }^{12}$ Our model in column (4) is suggestive of this mediation process: the coefficient for identity is positively related to job satisfaction even in the presence of the work characteristics variables $(b=0.29, p<.001)$. Overall, our model in column

(4) provides support for our hypothesis (1). As the attenuation of the identity variable from model

(2) to model (4) is rather modest, it can be argued that identity has a strong independent relationship with job satisfaction irrespective of work characteristics. We pursue this mediation hypothesis more formally in the subsequent subsection.

\subsection{Occupational Identity and Its Determinants}

Given the findings above on job satisfaction and our discussion of identity formation in the crafts, it is instructive to further analyze what drives occupational identity in our sample. In table 3 we present our regressions of identity on main activity at work (column 1) and vocational development stage (column 3). We also analyze how work characteristics are related to identity (column 2 and column 4).

With regard to main work activity carried out (column 1), we clearly see the pattern from figure 2 confirmed, i.e., office personnel have a less-strong occupational identity compared to the base category of pure craftsmen $(b=-0.65, p<.01)$. Of the latter, those who also run their own business have the strongest occupational identity $(b=0.27)$, but the difference is not statistically distinguishable from chance. There are good reasons to think that crafter-owners should develop the strongest sense of occupational identity due to a sense of ownership that a business entails, which employed craftsmen may not see so strongly (overall supporting hypothesis [3b]). Such a strong identity among craftsmen who run their own business might also be driven by family traditions often present in the skilled craft and trades, where the parental business is inherited and children are socialized into the craft at early ages in these families. Vocational development is

\footnotetext{
${ }^{12}$ Wegge et al. (2006) have shown that work characteristics correlate with organizational identification on the order of $r=.39$ and independently contribute to job satisfaction in their sample. They further test a moderating role for organizational identification for work characteristics on job satisfaction but could not find any evidence in support of this (i.e., nonsignificant interaction terms).
} 
also positively associated with occupational identity (even controlling for age), so that master craftsmen have a much stronger occupational identity compared to apprentices $(b=-1.38, p<$ $.01)$ and journey(wo)men $(b=-0.35)$ but differences in the latter case are not statistically significant. This provides us with partial support for hypothesis (3a). While it is possible that differences in identity between office personnel and crafters are due to endogenous job choice, i.e., individuals identifying already strongly with some craft self-select into that profession, the difference in identity between apprentices and master crafters show that identity differentials found in our analysis are not entirely due to self-selection. Considering that the coefficient due to vocational position is twice as large, self-selection cannot be considered to be the main driver for explaining identity differences.

Both main activity at work and vocational development stage would determine what set of work characteristics a crafter faces and hence become control variables when analyzing the relationship between work characteristics and occupational identity (columns 2 and 4). Patterns here are robust to including only main activity (column 2) or also adding vocational position (column 4 , which seriously decreases our sample by roughly 200 observations). We focus our discussion on the former model, as this keeps the same sample as in the previous discussion on job satisfaction. We can see that task significance (work is important, $\mathrm{b}=0.21, \mathrm{p}<.01$ ), task variety (new tasks, $\mathrm{b}$ $=0.21, \mathrm{p}<.01)$, skill variety $(\mathrm{b}=0.21, \mathrm{p}<.05)$, and social support (colleagues as friends, $\mathrm{b}=$ $0.19, \mathrm{p}<.001)$ are positively related to the occupational index variable, partially supporting our Hypothesis (2). We would have expected that task identity would also bear a positive relationship to occupational identity (in line with Inkson 1987; Pöllänen 2013), but cannot find supporting evidence for our sample (this also does not change when estimating this regression only for crafts(wo)men per se, i.e., excluding office workers and managers/owners). In our analysis, all work characteristics are jointly significantly related to occupational identity $(\mathrm{F}(14,653)=11.78$, $\mathrm{p}<.001)$ and adding work characteristics to the models significantly increases explanatory power as measured by the adjusted $\mathrm{R}^{2}$ of our regressions (from .17 to .35 , column 1 to 2 ).

Our analyses of the relationship between job satisfaction and identity as well as between identity and work characteristics are quite uniform in that additional analyses that interact identity with income and age in the job satisfaction regressions do not yield significant evidence for the heterogeneity of this relationship (a similar picture holds when interacting main activity and 
vocational position with income and age variables, both of which are not shown here). While our results might hold for the sample of crafters at hand, due to fact that our sample hasn't been a true random sample (see section 4.3), results might not generalize to the population of crafters in Germany. Based on information on crafters in the representative German SOEP and information on the demographics of crafters provided by the ifh Goettingen (2017), we were able to reweight our dataset with respect to gender, education, vocational position, self-employment status, and job satisfaction. ${ }^{13}$ Reestimating our main models this way (see table A8 and table A9) yields similar results with regard to the large and significant coefficient for occupational identity and the comparatively weak relationship between job satisfaction and income. With regard to work characteristics, there are some smaller discrepancies between the unweighted and weighted analysis, but skill variety and social support variables are significant in both analyses. The strong negative relationship between identity and apprenticeship is also preserved. While the large overlap in results convinces us that the lack of representativeness in some dimensions might not be too problematic, we hasten to add that the reweighting exercise itself is not a panacea and subject to a number of limitations, amongst them that it obviously only works for observable variables and the reweighted dataset might still be unrepresentative along unobservable dimensions. In addition, the population information from the SOEP comes from a slightly different time period than when our survey was conducted and data on the fractions of master crafters and apprentices are from some years before our sample, as no more up-to-date information was available to compute population weights.

\subsection{Occupational Identity as Mediator between Work Characteristics and Job Satisfaction}

To pursue more formally the idea that occupational identity mediates the effects of work characteristics on job satisfaction, we use a mediation approach based on Baron and Kenny (1986). Their method posits that a total effect of work characteristics on job satisfaction, such as the coefficients discussed in table 2, column (3), can be decomposed into a direct effect and an indirect effect that goes through occupational identity. While the Baron and Kenny method is

\footnotetext{
${ }^{13}$ We thank an anonymous referee for pointing out that such a reweighting might be a useful activity. Weighting sample data is generally poorly understood in applied work (Gelman 2007; Angrist and Pischke 2009: sect. 3.4.1) and usually not necessary to undertake in the modern control function approach to microeconometrics (Cameron and Trivedi 2010: sect 3.7.3).
} 
widely used in social science research, concerns have been raised about it in the literature (e.g., Zhao, Lynch, and Chen 2010; Bullock and Ha 2011; Rucker et al. 2011) and best practice has shifted over the last few years (Preacher and Hayes 2008; Hayes 2009; Gatignon 2014: ch. 11) to jointly estimating the following two regression equations,

$$
\begin{aligned}
& M_{i}=\alpha_{i}+\beta_{i} X+\gamma_{i} Z+\epsilon_{i, M} \\
& Y_{i}=\alpha_{i}+\beta_{i}^{\prime} X+\delta_{i} M+\gamma_{i} Z+\epsilon_{i, Y},
\end{aligned}
$$

where $\alpha$ denotes the constant, $\beta$ is the coefficient vector for work characteristics, $\beta$ ' the "direct effects" coefficient vector for work characteristics while controlling for the mediator, $\delta$ the coefficient of the mediator variable occupational identity, and $\gamma$ a vector of coefficients of control variables. Equation (5) regresses the mediator variable (M, occupational identity) on work characteristics (X) and equation (6) then regresses job satisfaction (Y) on both mediator and work characteristics variables. From this system of equations, an indirect effect of work characteristics on job satisfaction through occupational identity can be computed as $\frac{\partial J S}{\partial I D} * \frac{\partial I D}{\partial W D Q}, i . e . \beta_{i} * \delta_{i}$.

While we have computed these equations in table 2 and table 3 independently (compare equation [3] to equation [6] and equation [4] to equation [5]), a major concern is that the error terms of both equations are likely to be correlated due to omitted common factors, including other mediators (Bullock and Ha 2011). This implies that the independently estimated OLS coefficients will be biased. In addition, the coefficients that constitute the indirect effect are not independently distributed and their distribution is not normal (Zhao, Lynch, and Chen 2010; Preacher and Hayes 2008, 880). 


\section{Table 4: Mediation Analysis Estimating the Indirect Effect that Work Characteristics Have on Job Satisfaction through the Occupational Identity Variable}

\begin{tabular}{lccc} 
Variable & $\begin{array}{c}\text { Indirect effect } \\
\text { (and Bootstrap SE) }\end{array}$ & $\begin{array}{c}\text { Confidence Interval } \\
\text { (Bias-corrected) }\end{array}$ & $\begin{array}{c}\text { Comparison } \\
\text { (Total effect) }\end{array}$ \\
\hline Task identity: complete products/services & $0.09^{* *}(0.02)$ & $(0.05,0.14)$ & -0.02 \\
Task identity: complete work process & $0.07^{* *}(0.02)$ & $(0.04,0.10)$ & $0.09^{*}$ \\
Task significance: work has influence on others & $0.11^{* *}(0.02)$ & $(0.07,0.15)$ & $0.17^{* *}$ \\
Task significance: work is significant and important & $0.11^{* * *}(0.02)$ & $(0.08,0.16)$ & 0.01 \\
Task variety: new tasks & $0.14^{* * *}(0.03)$ & $(0.09,0.20)$ & $0.19^{* *}$ \\
Task variety: variety of tasks & $0.16^{* * *}(0.03)$ & $(0.10,0.23)$ & -0.04 \\
Skill variety: work requires various skills & $0.18^{* * *}(0.04)$ & $(0.11,0.26)$ & 0.04 \\
Specialization: work requires specialized skills & $0.09^{* * *}(0.02)$ & $(0.05,0.15)$ & -0.03 \\
Problem-solving: task with no clear solutions & $0.05^{* *}(0.02)$ & $(0.02,0.08)$ & -0.07 \\
Problem-solving: creativity is important for my work & $0.09^{* * *}(0.02)$ & $(0.05,0.13)$ & -0.01 \\
Social support: meet new people at work & $0.11^{* * *}(0.02)$ & $(0.07,0.15)$ & -0.08 \\
Social support: colleagues are also friends & $0.10^{* * *}(0.02)$ & $(0.07,0.14)$ & $0.07^{*}$ \\
Autonomy: can make many decisions on my own & $0.13^{* * *}(0.03)$ & $(0.08,0.18)$ & $0.16^{*}$ \\
Autonomy: abilities allow different approaches & $0.13^{* * *}(0.03)$ & $(0.08,0.19)$ & 0.01 \\
\hline
\end{tabular}

Notes: Bootstrapped indirect coefficients for work characteristics/identity mediation analysis presented here (biascorrected bootstrap 95 percent confidence intervals, 5,000 repetitions). Each indirect coefficient represents a separate mediation model that holds all other work characteristics constant. All control variables from above analysis present but not depicted here. Total effects referenced as comparison from table 2, column 3 .

Source: Own data.

To account for correlated errors across equations, we estimate the two key equations representing the mediation process as a (recursive) system of equations using seemingly unrelated regressions (SUR), a method equivalent to a type of structural equation model widely used outside of economics (see Zellner, 1962). In addition, following Preacher and Hayes (2008) and Hayes (2009), we also bootstrap the standard error of the coefficient for the indirect effect so that we do not require a normal distribution of the indirect effect's test statistic.

Reestimating our main models combining SURs and the Hayes and Preacher bootstrap procedure allows us to derive bootstrapped indirect effects of our work characteristics variables and test whether these are significantly different from zero (as shown in table 4). We can see that all indirect effects are significantly different from zero, i.e., all work characteristics are mediated by occupational identity in their impact on job satisfaction. Overall, this provides strong evidence in favor of hypothesis (4). It is interesting to note that the indirect effect coefficients are smaller than the comparison total effects from the unmediated model in some cases (e.g., the autonomy variable relating to own decision making), pointing to a separate positive direct contribution of this variable to job satisfaction. In other cases, smaller or nonsignificant total effects suggest countervailing direct effects that cancel some of the indirect effect. That some of the total effects 
are statistically insignificant despite significant indirect effects can have multiple explanations such as suppression (when a second mediator for this variable is present that has an effect in the opposite direction) but can also be related to differential power of the analysis regarding indirect versus total effects, strength of the relationship between independent variables on mediator versus mediator on dependent variable, measurement precision for the different variables, and so on (Rucker et al. 2011; Zhao, Lynch, and Chen 2010). As this is not related to our research hypothesis (4), and might be specific to individual work characteristics, we leave for future research further theorizing to explain these findings as well as testing in an independent sample.

\section{NORM-RELATED EFFECTS OF IDENTITY ON WELL-BEING}

In the following, we provide a rough measure of $t_{i, c}\left|e^{*}(c)-e_{i}\right|$ in the model developed by Akerlof and Kranton (2005), i.e., a person's importance-weighted deviation in terms of effort $e_{i}$ from an ideal effort level $e^{*}(c)$ associated with the relevant identity category $c$. Our goal is to explore the norm-related relative effects that a craftsman's identity may have on worker wellbeing. Having a strong identity and exerting an effort not in alignment with such identity has been hypothesized to carry a negative utility premium in the model of Akerlof and Kranton (2005), independently of the utility stemming from identification with a social category $\left(t_{i, c}\left|e^{*}(c)-e_{i}\right|\right.$ vs. $\left.I_{c}\right)$. This utility loss can be understood as the result of lack of conformity with a norm. Akerlof and Kranton $(2003,43)$ admit that this term might be empirically hard to measure and potentially easier to capture in its whole form by measuring conformity to some ideal instead of measuring $e^{*}(c)$ or $t_{i, c}$ in isolation. However, we would argue that the optimal effort level associated with a social category might be proxied by a variable averaging the effort shown by others in that category (who by their behavior implicitly define the appropriate level).

Our dataset allows us to examine norm-related effects of identity on well-being in the following way: we compute group-specific ideal effort levels, $e^{*}(c)$, by alternatively averaging hours worked and intrinsic work motivation by main work activity (i.e., we do this here for office workers versus craftsmen, firm leaders) essentially arguing that these activity categories (roughly) map onto identity categories and define social categories, $c$. We then compute a 
measure of deviation from the norm set by the reference group by taking the difference in hours worked (or intrinsic motivation) of a respondent to the average of hours worked (or intrinsic motivation) in their respective group (in order not to confound full-time with part-time workers here, we drop the few individuals not working full time in our sample for this analysis). This allows us to capture $\left|e^{*}(c)-e_{i}\right|$. Since deviation from the norm can be both positive and negative, we then create dummy variables for individuals belonging to the 25 percent and 75 percent quantiles of the deviation distribution, with the former denoting "less than norm" and the latter "more than norm" individuals. By this we can account for the direction of deviation instead of focusing on the absolute value of the deviation and explore whether overfulfilment and underfulfillment have different effects. What we cannot easily capture is the importance weight, $t_{i, c}$, but by computing interaction effects of the norm term with the identity $I_{c}$ term, we model the importance weighting under the assumption that the level of identity defines the importance individuals attach to conforming with the norm. We would expect that increasing identity levels would lead to higher impact of norm deviation with regard to well-being. In addition, we would further expect the overfulfilment of the norm to be positively related to well-being for high identity individuals and negatively related to well-being for low identity individuals. The converse would be true of underfulfillment.

While hours worked can be seen as an objective measure of one's effort level, there might be limits regarding the extent to which individuals can control their work hours to match their desired effort level (full-time work legally comprises a set amount of work in Germany, usually around 37.5-40 hours) and working more or less might not be possible, independent of how much an individual identifies with their job. For this reason, we also measure effort level by the subjectively assessed level of intrinsic motivation individuals report in the questionnaire. Respondents were asked to express agreement with the following statement: "I would still do this work, even if I received less pay" on a seven-point Likert scale. Here again, the deviation from the group mean value can be seen as a coarse measure of how aligned an individual is with the work norms associated with their identity category. In this case, too, we focus on the 25 percent and 75 percent quantiles of the deviation distribution, with the former denoting "less than norm" and the latter "more than norm" individuals. The literature on social identity conceives of intrinsic motivation as an outcome of identification with a social category (i.e., whether certain work is seen as intrinsically motivating depends on one's identity, see, e.g., Haslam [2004] and 
Ashforth, Harrison, and Corley [2008, 337]), which bolsters our argument that it can serve as a variable measuring how strongly individuals identify with the norms of their social category in terms of work effort shown. Its shortcoming is that it only indirectly captures the actual effort level shown, i.e., it remains unclear whether the craftsman actually translates their motivation into work effort.

Results for regressing job satisfaction on these variables are presented in table 5. We can find some evidence for norm effects present but only for the intrinsic motivation variable (column 1): we can see that underfulfillment of the norm is negatively associated with job satisfaction, whereas overfulfilment is positively associated with job satisfaction. On the other hand, working fewer or more hours than one's peer group is not statistically significantly associated with a change in job satisfaction (column 3).

In order to capture the importance weighting $t_{i, c}$ of the Akerlof and Kranton (2005) model, we would need to see differential effects depending on the level of occupational identity, i.e., high identity individuals exhibiting high work motivation/work hours should have higher work satisfaction, but also low identity individuals with low work motivation/work hours should have higher work satisfaction and vice versa. Estimating these models and interacting identity with our effort variables yields no significant interaction effects (see columns 2 and 4). In our dataset, we thus cannot find evidence for relative effects of the sort conceptualized in the formal model. Rather, we find that norm-related effects are present irrespective of individuals' importance weighting (as measured by their level of identity). In both cases, these norm effects seem to be asymmetric. It has to be noted that our variables chosen here are coarse proxies for effort levels and importance of work norms for the individual. Our work here is exploratory and should be considered a first step in an attempt at more specific theorizing and measurement of such effects in future research. 
Table 5: Analysis Capturing a Potential Impact that One's Deviation of Own Effort from an Effort Norm of One's Social Category Has on Job Satisfaction

\begin{tabular}{|c|c|c|c|c|}
\hline & (1) & (2) & (3) & $(4)$ \\
\hline DV: Job satisfaction & Intr. Motivation & + Interactions & Hours worked & + Interactions \\
\hline Identity index (pca) & $\begin{array}{c}0.24^{* * *} \\
(5.33)\end{array}$ & $\begin{array}{c}0.29^{* * *} \\
(5.09)\end{array}$ & $\begin{array}{c}0.31^{* * *} \\
(7.33)\end{array}$ & $\begin{array}{c}0.32^{* * *} \\
(6.74)\end{array}$ \\
\hline \multicolumn{5}{|l|}{ Intr. Motivation } \\
\hline Less than norm & $\begin{array}{c}-0.52^{* * *} \\
(-3.82)\end{array}$ & $\begin{array}{c}-0.54 * * * \\
(-3.85)\end{array}$ & & \\
\hline More than norm & $\begin{array}{c}0.28^{*} \\
(1.98)\end{array}$ & $\begin{array}{c}0.28 \\
(1.51)\end{array}$ & & \\
\hline \multicolumn{5}{|l|}{ Intr. Motivation, interactions } \\
\hline Less than norm $x$ Identity index (pca) & & $\begin{array}{c}-0.09 \\
(-1.15)\end{array}$ & & \\
\hline More than norm x Identity index (pca) & & $\begin{array}{c}-0.04 \\
(-0.29)\end{array}$ & & \\
\hline \multicolumn{5}{|l|}{ Hours worked } \\
\hline Less than norm & & & $\begin{array}{c}0.17 \\
(1.27)\end{array}$ & $\begin{array}{c}0.17 \\
(1.28)\end{array}$ \\
\hline More than norm & & & $\begin{array}{c}-0.09 \\
(-0.63)\end{array}$ & $\begin{array}{c}-0.09 \\
(-0.61)\end{array}$ \\
\hline \multicolumn{5}{|l|}{ Hours worked, interactions } \\
\hline Less than norm $x$ Identity index (pca) & & & & $\begin{array}{c}-0.01 \\
(-0.08)\end{array}$ \\
\hline More than norm x Identity index (pca) & & & & $\begin{array}{c}-0.03 \\
(-0.26)\end{array}$ \\
\hline Constant & $\begin{array}{l}5.51^{* * *} \\
(4.77)\end{array}$ & $\begin{array}{l}5.51^{* * *} \\
(4.73)\end{array}$ & $\begin{array}{l}5.74^{* * *} \\
(4.96)\end{array}$ & $\begin{array}{l}5.77^{* * *} \\
(4.95)\end{array}$ \\
\hline Controls & Yes & Yes & Yes & Yes \\
\hline Observations & 704 & 704 & 710 & 710 \\
\hline $\mathrm{F}$ & 12.79 & 12.28 & 11.53 & 11.58 \\
\hline Degrees of freedom & 614.00 & 614.00 & 620.00 & 620.00 \\
\hline Adj. $R^{2}$ & 0.30 & 0.30 & 0.28 & 0.28 \\
\hline
\end{tabular}

$t$ statistics in parentheses
${ }^{+} p<0.10,{ }^{*} p<0.05,{ }^{* *} p<0.01,{ }^{* * *} p<0.001$

Notes: Models (1) and (2) capture effort and norm deviation via self-reported intrinsic motivation and models (3) and (4) repeat the analysis using hours worked as measure of effort. Norm deviation is measured as reporting higher or lower effort compared to one's social group as defined by the main activity at work variable. OLS regressions, where the dependent variable is job satisfaction. Heteroscedasticity-robust standard errors clustered on the postal code level. Control variables as in previous models but not shown here.

Source: Own data.

\section{CONCLUSION}

Not all jobs are created equal. With the seeming proliferation of "bullshit jobs" (Graeber 2018) in modern societies, it becomes important to understand why some jobs are so much more meaningful and more conducive to worker well-being than others. In the present paper, we have traced worker well-being (measured as job satisfaction) back to the degree of occupational 
identity that is engendered by the job, and we have shown that occupational identity itself is partly influenced by a number of work characteristics associated with the job.

The literature on occupational identity has established the importance of this facet of a person's overall identity for well-being, but most studies have only focused on organizational identification (a somewhat narrow reflection of occupational identity) and its relation to job satisfaction (Van Dick et al. 2008; Riketta and Van Dick 2005). In addition, evidence on the crafts sector has been purely qualitative and based on case studies so far. Using the model of Akerlof and Kranton (2005), we have extended a social identity perspective (Tajfe 1974; Ashforth, Harrison, and Corley 2008) by relational and personal elements inherent in one's occupational identity, where the former are linked to significant social interactions a worker has in their job and the latter to work characteristics of the work conducted itself.

Using a unique dataset of German workers in the skilled crafts and trades and creating a measure of occupational identity that involves both cognitive and affective elements, we have found that higher job satisfaction is related to a stronger sense of occupational identity in our sample. This relationship is quite sizable and robust across model specifications, whereas the relationship between income and job satisfaction is fragile in comparison. Identity increases in vocational development and is higher for crafts(wo)men not involved in administrative and office work (it is also more pronounced for those leading their own firm). We have shown that occupational identity is positively associated with a number of work characteristics, viz. task significance and task and skill variety, as well as social support, and our analysis confirms that identity mediates the influence of these characteristics with regard to job satisfaction.

Our study is not without limitations. First, cross-sectional data can lend itself to causal interpretation only in the face of a strong theory and reverse causality is not implausible in our case (higher job satisfaction might help strengthen occupational identity). Still, we have to note that at least with regard to omitted variable bias, we are able to control for many of the wellknown confounds that have been identified in the literature, importantly amongst them personality traits that likely are related to both sides of our regression equation. In addition, the literature on job satisfaction provides good evidence and theoretical support for our interpretation that the predominant causal direction is from work characteristics and occupational identity to job 
satisfaction. Similarly, the literature on job satisfaction and income has documented how unreliable and modest the impact of income on job satisfaction is (Judge et al. 2010), providing independent support for our findings and our argument that an extended utility function should prominently figure additional factors. Work characteristics have been already identified as strong predictors for job satisfaction (Humphrey, Nahrgang, and Morgeson 2007), and our work now adds occupational identity as strong predictor, especially considering that we identified identity as mediator, and hence as a substantive explanation for the relationship between work characteristics and job satisfaction.

As regards self-selection of high identity individuals into the crafts profession, we similarly cannot exclude this possibility, but as discussed above, identity increases over the vocational stages and if we consider the difference in identity between crafters and office personnel to be partly due to self-selection, we then can note that the identity differences between apprentices and master crafters are twice as big as the difference between office workers and crafters so that even in the face of identity-driven self-selection into the profession, a substantive strengthening of one's professional identity apparently takes place over the vocational development phases.

Secondly, due to the nature of the questionnaire distribution, we oversample both highly educated craftsmen, as well as those that are master craftsmen and those who are self-employed. While reweighting the dataset along a number of observable characteristics has preserved our main findings, we cannot guarantee that the reweighted dataset is fully representative because unobserved characteristics might still be different between our sample and the population. Given the lack of appropriate occupational identity and work characteristics variables in large household panel surveys, future research should aim at distributing a more representative survey. However, given the strong support the German crafter lobby has given to our survey and its distribution, it can be asked whether a significantly better result might be realistically achieved here.

Thirdly, the literature on occupational identity is fragmented and many different measures of identity abound, without a clear consensus on its relevant constituent parts and the required items to measure it. Future work should aim at more systematically validating our measure of occupational identity. 
Finally, we have focused on a specific type of jobs and the question to what extent our findings would generalize to other professions, say, professors or lawyers, should be the topic of future research. However, while crafters may have a specific set of work characteristics as well as score highly in specific dimensions of the WDQ measures, other jobs can be ranked similarly in terms of WDQ, and we would expect that the relationship between job satisfaction and work characteristics is not limited to our sample. Indeed, previous research on the WDQ has shown them to be connected to job satisfaction, and specifically autonomy and relatedness (social support) have seen strong support. What needs further confirmation is the relationship between work characteristics and occupational identity as well as the mediating role the latter plays. As our work here is novel in analyzing this, independent replication attempts, with crafter samples as well as other samples, seem desirable.

These limitations notwithstanding, it can be conjectured that a strong sense of occupational identity will be important for worker well-being in any kind of job and finding out how to create more jobs that are meaningful and have work characteristics that induce a heightened sense of identity would constitute worthwhile future research. Our research here highlights that while some work features associated with occupational identity might vary across different professions (embodied cognition, using tools as extensions of one's body, and body knowledge), others seem more general across professions (task identity, task significance, social support, autonomy).

Our study is also relevant regarding the question of motivating workers. With limited influence of incentive schemes on worker motivation, occupational identity can be an additional factor to ensure worker motivation (Akerlof and Kranton 2005): not only can identification with a company foster identity, but also the work itself, if it is holistic and of significance, and if the work conditions allow for social support and autonomous decision making by the worker. While these conditions are a given in many crafts firms, highly specialized jobs may come with the opposite of such work characteristics and division of labor may increase worker productivity at first but dull the job to an extent that worker satisfaction and productivity in turn may suffer. Highly specialized work need not be "bullshit" and can contribute to the production of useful things, but the individual worker contributing to it nevertheless may lack a sense of meaning and significance and hence be dissatisfied with their job in comparison. Our work here supports the idea of reducing specialization and going back to more holistic work practices when societal 
goals are not just about producing the most it can but also providing meaningful and satisfying jobs for their workers. This trade-off between output and job satisfaction (resulting from quality of work) may be a loose analogy of Easterlin's paradox in that rising productivity through everincreasing specialization might not engender rising satisfaction of the workforce (compare Easterlin [1974]).

Our work is also relevant more narrowly when it comes to labor shortages: for instance, with a shortage of skilled labor in Germany ("Fachkräftemangel”), implementing policies that strengthen occupational identity and advertising the significance of the work being done can be used to increase labor supply. Such policies could encompass a strengthening of the current dual vocational apprenticeship system in Germany (as opposed to trying to move the system in the direction of a less embodied bachelor's degree education, which might well weaken occupational identity in the crafts sector and hence decrease work well-being) as well as reinstating previously abolished formal examinations for master crafters as one of the contributors to such a sense of occupational identity and pride. 


\section{Acknowledgements}

The questions pursued in the current interdisciplinary research project (www.handwerksstolz.de) and this article emerged in the context of an interdisciplinary research project with cultural anthropologists investigating craft innovation and tacit knowledge. The questionnaire used in this study was jointly designed with D. Hemme. We are grateful for the input she provided based on her qualitative research and interviews conducted with German crafts(wo)men. Special thanks also to Kilian Bizer (Chair of Economic Policy and SME Research) for his support. We further want to thank Harm Alhusen, Regina Bendix, Georg Christiansmeyer, Benita Gandorfer, Hanna M. Sasse, Helene Schuele, Benjamin Schulze, Joerg Thomae, and Judith Venherm. The manuscript has been presented at the STATEC Well-being Seminar Series and we'd like to thank seminar participants for helpful comments and suggestions. We are grateful to Titus Kockel and the $\mathrm{ZDH}$ for the distribution of the questionnaire. Finally, we wish to thank two anonymous referees as well as our handling editor, David Stadelmann, for helpful comments and suggestions. This research project was funded by the Ministry of Science and Culture of Lower Saxony 76251-10-6/18 (ZN3405). We acknowledge financial support by Universität der Bundeswehr München.

\section{Declarations of interest}

None

\section{Data availability}

Replication files are provided in the supplementary material. 


\section{REFERENCES}

Akerlof, G., and R. Kranton. 2010. Identity economics. Princeton, NJ: Princeton University Press.

_. 2008. "Identity, supervision, and work groups." American Economic Review 98(2): 21217.

- 2005. "Identity and the economics of organizations." The Journal of Economic Perspectives 19(1): 9-32.

—. 2003. "Identity and the economics of organizations." Mimeo.

—. 2000. "Economics and identity." Quarterly Journal of Economics: 715-53.

Angrist, J. D., and J.-S. Pischke. 2009. Mostly Harmless Econometrics. Princeton, NJ: Princeton University Press.

Ashforth, B. E., S. H. Harrison, and K. G. Corley. 2008. "Identification in organizations: An examination of four fundamental questions." Journal of Management 34(3): 325-74.

Bade, K. J. 1982. „Altes handwerk, wanderzwang und gute policy: Gesellenwanderung zwischen zunftökonomie und gewerbereform.“ VSWG: Vierteljahrschrift für Sozial- und Wirtschaftsgeschichte 69(H. 1): 1-37.

Baron, R. M., and D. A. Kenny. 1986. "The moderator-mediator variable distinction in social psychological research: Conceptual, strategic, and statistical considerations." Journal of Personality and Social Psychology 51(6): 1173.

Becker, H. S., and J. W. Carper. 1956. "The development of identification with an occupation." American Journal of Sociology 61(4): 289-98.

Ben-Ner, A., B. P. McCall, M. Stephane, and H. Wang. 2009. "Identity and in-group/out- group differentiation in work and giving behaviors: Experimental evidence." Journal of Economic Behavior \& Organization 72(1): 153-70.

Benjamin, D. J., J. J. Choi, and A. J. Strickland. 2010. "Social identity and preferences." American Economic Review 100(4): 1913-28.

Berg, C. 2017. "Zusammenhänge zwischen beruflicher identität, commitment und arbeitszufriedenheit.” Zeitschrift für Arbeitswissenschaft 71(3): 169-78.

Blau, G. J. 1985. "The measurement and prediction of career commitment." Journal of Occupational Psychology 58(4): 277-88.

Braithwaite, N. 2017. "Sensing creativity: the role of materials in show design." The Senses and Society 12(1): 90-94. 
Bullock, J. G., and S. E. Ha. 2011. "Mediation analysis is harder than it looks.” In J. N. Druckman, D. P. Green, J. H. Kuklinski, and A. Lupia (eds.), Cambridge Handbook of Experimental Political Science. Cambridge, UK: Cambridge University Press.

Cameron, A. C., and P. K. Trivedi. 2010. Microeonometrics Using Stata. College Station: Stata Press.

Carson, K. D., and A. G. Bedeian. 1994. "Career commitment: Construction of a measure and examination of its psychometric properties.” Journal of Vocational Behavior 44(3): 23762.

Caruso, R., M. Di Domizio, and D. A. Savage. 2017. "Differences in national identity, violence and conflict in international sport tournaments: hic sunt leones!" Kyklos 70(4): 511-45.

Chan, S. 2014. "Crafting an occupational identity: Learning the precepts of craftsmanship through apprenticeship." Vocations and Learning 7: 313-30.

Christiansen, C. H. 1999. "Defining lives: Occupation as identity: An essay on competence, coherence, and the creation of meaning." American Journal of Occupational Therapy 53(6): 547-58.

Clark, A., A. Oswald, and P. Warr. 1996. "Is job satisfaction u-shaped in age?" Journal of Occupational and Organizational Psychology 69(1): 57-81.

Clark, A. E. 1997. “Job satisfaction and gender: Why are women so happy at work?" Labour Economics 4(4): 341-72.

Corson, D. J. 1985. "Education for work: Reflections towards a theory of vocational education." International Review of Education 31(1): 283-302.

Cramer, G., and K. Müller. 2011. Quo vadis Handwerk? Identität des Handwerks im Wandel. Duderstadt: Mecke Druck und Verlag.

Crawford, M. 2010. The Case for Working with Your Hands: Or why office work is bad for us and fixing things feels good. London: Penguin UK.

Dabke, S., O. Salem, A. Genaidy, and N. Daraiseh. 2008. "Job satisfaction of women in construction trades." Journal of Construction Engineering and Management 134(3): 20516.

D’Addio, A. C., T. Eriksson, and P. Frijters. 2007. “An analysis of the determinants of job satisfaction when individuals' baseline satisfaction levels may differ." Applied Economics 39(19): 2413-23.

Deci, E. L., and R. M. Ryan. 2000. “The 'what' and 'why' of goal pursuits: Human needs and the self-determination of behavior.” Psychological Inquiry 11(4): 227-68. 
Dickie, V. A. 2003. "Establishing worker identity: A study of people in craft work." American Journal of Occupational Therapy 57(3): 250-61.

Dobrow, S. 2004. "Extreme subjective career success: A new integrated view of having a calling." In S. Taneja (ed.), Academy of Management Proceedings, volume 2004. Briarcliff Manor, NY: Academy of Management.

Easterlin, R. A. 1974. "Does economic growth improve the human lot? Some empirical evidence." In P. David and M. Reder (eds.), Nations and Households in Economic Growth. New York and London: Academic Press.

Eckel, C. C., and P. J. Grossman. 2005. "Managing diversity by creating team identity.” Journal of Economic Behavior \& Organization 58(3): 371-92.

Ferrer-i-Carbonell, A., and P. Frijters. 2004. "How important is methodology for the estimates of the determinants of happiness?" The Economic Journal 114 :641-59.

Fisher, C. D. 2010. “Happiness at work.” International Journal of Management Reviews 12(4): 384-412.

Freeman, R. 1978. “Job satisfaction as an economic variable." American Economic Review 68(2): 135-41. (Reprinted in Race and Public Policy: The Irony of Equity, C. Sampson [ed.]: Dubuque, IA: Kendal/Hunt Publishing).

Gaertner, C. 2013. "Cognition, knowing and learning in the flesh: Six views on embodied knowing in organization studies." Scandinavian Journal of Management 29: 338-52.

Gatignon, H. 2014. Statistical analysis of management data, 3rd edition. Amsterdam: Springer.

Gelman, A. 2007. "Struggles with survey weighting and regression modeling." Statistical Science 22(2): 153-64.

Graeber, D. 2018. Bullshit Jobs: A Theory. New York: Simon \& Schuster.

Gupta, A., S. Chong, and F. T. L. Leong. 2015. "Development and validation of the vocational identity measure." Journal of Career Assessment 23(1): 79-90.

Hackman, J. R., and G. R. Oldham. 1975. "Development of the job diagnostic survey." Journal of Applied Psychology 60(2): 159.

- 1976. "Motivation through the design of work: Test of a theory." Organizational Behavior and Human Performance 16(2): 250-79.

Hall, D. T., and R. Mansfield. 1971. "Organizational and individual response to external stress." Administrative Science Quarterly 16(4).

Haslam, S. A. 2004. Psychology in organizations. Sage. 
Haybron, D. M. 2007. "Life satisfaction, ethical reflection, and the science of happiness." Journal of Happiness Studies 8: 99-138.

Hayes, A. F. 2009. "Beyond Baron and Kenny: Statistical mediation analysis in the new millennium." Communication Monographs 76(4): 408-20.

Hemme, D., and A.-K. Blankenberg. 2019. "Handwerkstolz.de - Werkstattbericht zu einem Projekt inter- und transdisziplinärer Glücksforschung im Handwerk. " In S. Groth, S. May, and J. Müske (eds.), Vernetzt, entgrenzt, prekär? Kulturwissenschaftliche Perspektiven auf Arbeit im Wandel. Frankfurt/Main: Campus.

Hirschi, A. 2011. "Callings in career: A typological approach to essential and optional components." Journal of Vocational Behavior 79(1): 60-73.

Holland, J. L., J. A. Johnston, and N. F. Asama. 1993. "The vocational identity scale: A diagnostic and treatment tool." Journal of Career Assessment 1(1): 1-12.

Humphrey, S. E., J. D. Nahrgang, and F. P. Morgeson. 2007. "Integrating motivational, social, and contextual work design features: a meta-analytic summary and theoretical extension of the work design literature." Journal of Applied Psychology 92(5): 1332-56.

Idson, T. L. 1990. "Establishment size, job satisfaction and the structure of work." Applied Economics 22(8): 1007-18.

ifh Goettingen. 2017. "MARKTFORSCHUNG Strukturanalyse SHK-Handwerk Update 2017." Studie des Zentralverbands Sanitaer, Heizung, Klima (ZVSHK).

Inkson, K. 1987. "The craft ideal and the integration of work: a study of potters." Human Relations 40(3): 163-76.

Judge, T. A., and J. E. Bono. 2001. "Relationship of core self-evaluations traits-self-esteem, generalized self-efficacy, locus of control, and emotional stability - with job satisfaction and job performance: A meta-analysis." Journal of Applied Psychology 86(1): 80-92.

Judge, T. A., D. Heller, and M. K. Mount. 2002. "Five-factor model of personality and job satisfaction: A meta-analysis.” Journal of Applied Psychology 87(3): 530.

Judge, T. A., and J. D. Kammeyer-Mueller. 2012. "Job attitudes.” Annual Review of Psychology 63: $341-67$.

Judge, T. A., and R. Klinger. 2007. “Job satisfaction: Subjective well-being at work.” In M. Eid and R. J. Larsen (eds.), The Science of Subjective Well-Being. New York and London: Guilford Press. 
Judge, T. A., R. F. Piccolo, N. P. Podsakoff, J. C. Shaw, and B. L. Rich. 2010. "The relationship between pay and job satisfaction: A meta-analysis of the literature." Journal of Vocational Behavior 77(2): 157-67.

Kahneman, D., P. P. Wakker, and R. Sarin. 1997. "Back to Bentham? Explorations of experienced utility." The Quarterly Journal of Economics 112(2): 375-406.

Klotz, V. K., S. Billett, and E. Winther. 2014. "Promoting workforce excellence: formation and relevance of vocational identity for vocational educational training." Empirical Research in Vocational Education and Training 6(1): 6.

Kroger, J. 2006. Identity development: Adolescence through adulthood. Thousand Oaks, CA: Sage Publications.

Krueger, A. B., and D. A. Schkade. 2008. "The reliability of subjective well-being measures." Journal of Public Economics 92(8-9): 1833-45.

Lee, E.-S., T.-Y. Park, and B. Koo. 2015. "Identifying organizational identification as a basis for attitudes and behaviors: A meta-analytic review." Psychological Bulletin 141(5): 104980.

Locke, E. A. 1969. "What is job satisfaction?" Organizational Behavior and Human Performance 4(4): 309-36.

Lucas, R. E. 2018. Reevaluating the strengths and weaknesses of self-report measures of subjective well-being. Handbook of well-being. Salt Lake City: DEF Publishers.

Mael, F., and B. E. Ashforth. 1992. "Alumni and their alma mater: A partial test of the reformulated model of organizational identification." Journal of Organizational Behavior 13(2): 103-23.

Marchand, T. H. 2008. "Muscles, morals and mind: Craft apprenticeship and the formation of person." British Journal of Educational Studies 56(3): 245-71.

— 2010a. "Embodied cognition and communication: studies with British fine woodworkers." Journal of the Royal Anthropological Institute 16(s1): S100-20.

— 2010b. "Making knowledge: explorations of the indissoluble relation bet- ween minds, bodies, and environment." The Journal of the Royal Anthropological Institute 16: S1-21.

- 2012. "Knowledge in hand: explorations of brain, hand and tool." In R. Fardon, O. Harris, T. H. J. Marchand, C. Shore, V. Strang, R. Wilson, and M. Nuttall (eds.), The Sage Handbook of Social Anthropology. Thousand Oaks, CA: Sage Publications.

—. 2016. "Introduction." In T. H. J. Marchand (ed.), Craftwork as Problem Solving. London: Routledge. 
Miscenko, D., and D. V. Day. 2016. "Identity and identification at work." Organizational Psychology Review 6(3): 215-47.

Morgeson, F. P., and S. E. Humphrey. 2006. "The work design questionnaire (WDQ): developing and validating a comprehensive measure for assessing job design and the nature of work." Journal of Applied Psychology 91(6): 1321.

O'Connor, E. 2005. "Embodied knowledge: The experience of meaning and the struggle towards proficiency in glassblowing." Ethnography 6(2): 183-204.

Paxson, H. 2012. The life of cheese: Crafting food and value in America. Berkeley, CA: University of California Press.

Polanyi, M. (1962[2005]). Personal knowledge. London: Routledge.

Pöllänen, S. 2013. "The meaning of craft: Craft makers' descriptions of craft as an occupation." Scandinavian Journal of Occupational Therapy 20(3): 217-27.

Preacher, K. J., and A. F. Hayes. 2008. “Asymptotic and resampling strategies for assessing and comparing indirect effects in multiple mediator models." Behavior Research Methods 40(3): 879-91.

Riketta, M., and R. Van Dick. 2005. "Foci of attachment in organizations: A meta-analytic comparison of the strength and correlates of workgroup versus organizational identification and commitment." Journal of Vocational Behavior 67(3): 490-510.

Rosensträter, H. 1964. "Das Meister-lehrling-und das lehrer-schüler-verhältnis im vergleich zur vater-sohn-beziehung." Jahrbuch für Christliche Sozialwissenschaften 5: 107-25.

Rucker, D. D., K. J. Preacher, Z. L. Tormala, and R. E. Petty. 2011. "Mediation analysis in social psychology: Current practices and new recommendations." Social and Personality Psychology Compass 5(6): 359-71.

Sandgruber, R., H. Bichler-Ripfel, and M. Walcher. 2016. “Traditionelles Handwerk als immaterielles Kulturerbe und Wirtschaftsfaktor in Österreich." Studie der Österreichischen UNESCO-Kommission im Auftrag des Bundeskanzleramtes und des Bundesministeriums Für Wissenschaft, Forschung und Wirtschaft Wien.

Sennett, R. 2008. The Craftsman. New Haven, CT: Yale University Press.

Skorikov, V. B., and F. W. Vondracek. 2011. "Occupational identity." In K. Luyckx, S. J. Schwartz, and V. L. Vignoles (eds.), Handbook of Identity Theory and Research. New York: Springer.

Steg, L. 2015. "Environmental psychology and sustainable consumption.” In L. A. Reisch and J. Thogersen (eds.), Handbook of Research on Sustainable Consumption. Edward Elgar,. 
Stegmann, S., R. Van Dick, J. Ullrich, J. Charalambous, B. Menzel, N. Egold, and T. Wu. 2010. "Der Work Design Fragebogen-Vorstellung und erste Validierung einer deutschen Fassung [the work design questionnaire - introduction and validation of a German version]." Zeitschrift für Arbeits—und Organisationspsychologie 54: 1-28.

Tajfel, H. 1974. "Social identity and intergroup behaviour." Social Science Information/sur les sciences sociales 13(2): 65-93.

- 1981. Human groups and social categories: Studies in social psychology. Cambridge, UK: Cambridge University Press.

Thurnell-Read, T. 2014. "Craft, tangibility and affect at work in the microbrewery." Emotion, Space and Society 13: 46-54.

Van Dick, R., and S. Stegmann. 2015. "Sinnvolle Arbeit ist identitätsstiftend - zur Bedeutung der sozialen Identifikation als Wirkmechanismus zwischen Bedeutsamkeit der Aufgabe und Arbeitseinstellungen." Arbeit 24(1-2): 40-65.

Van Dick, R., D. Van Knippenberg, R. Kerschreiter, G. Hertel, and J. Wieseke. 2008. "Interactive effects of work group and organizational identification on job satisfaction and extra-role behavior." Journal of Vocational Behavior 72(3): 388-99.

Van Knippenberg, D., and E. C. Van Schie. 2000. "Foci and correlates of organizational identification." Journal of Occupational and Organizational Psychology 73(2): 137-47.

Verhaegen, S., M. Hooghe, and E. Quintelier. 2014. "European identity and support for European integration: A matter of perceived economic benefits?” Kyklos 67(2): 295-314.

Vila, L. E., and B. Garcia-Mora. 2005. "Education and the determinants of job satisfaction." Education Economics 13(4): 409-25.

Warr, P. 1992. “Age and occupational well-being.” Psychology and Aging 7(1): 37.

Wegge, J., R. Van Dick, G. K. Fisher, C. Wecking, and K. Moltzen. 2006. "Work motivation, organisational identification, and well-being in call centre work." Work \& Stress 20(1): $60-83$.

Whitmarsh, L., and S. O’Neill. 2010.” Green identity, green living? The role of proenvironmental self-identity in determining consistency across diverse pro-environmental behaviours." Journal of Environmental Psychology 30(3): 305-14.

ZDH. 2017. "Daten und Fakten zum Handwerk fuer das Jahr 2017." Available at: https://www.zdh.de/fileadmin/user_upload/themen/wirtschaft/statistik/kennzahlen/Kennza hlen_2017/Flyer-2017-Tabelle-Veroeffentlichung.pdf (last accessed: Jan 1, 2020).

Zellner, A. 1962. "An efficient method of estimating seemingly unrelated regressions and tests for aggregation bias." Journal of the American Statistical Association 57(298): 348-68. 
Zhao, X., J. G. Lynch Jr., and Q. Chen. 2010. "Reconsidering Baron and Kenny: Myths and truths about mediation analysis." Journal of Consumer Research 37(2): 197-206. 


\section{APPENDIX}

Table A1: Pairwise Correlation Table Including Work Variables for the Main Estimation Sample

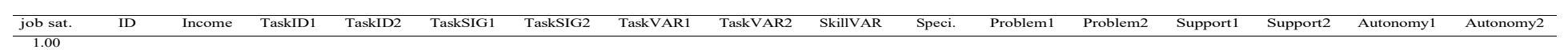

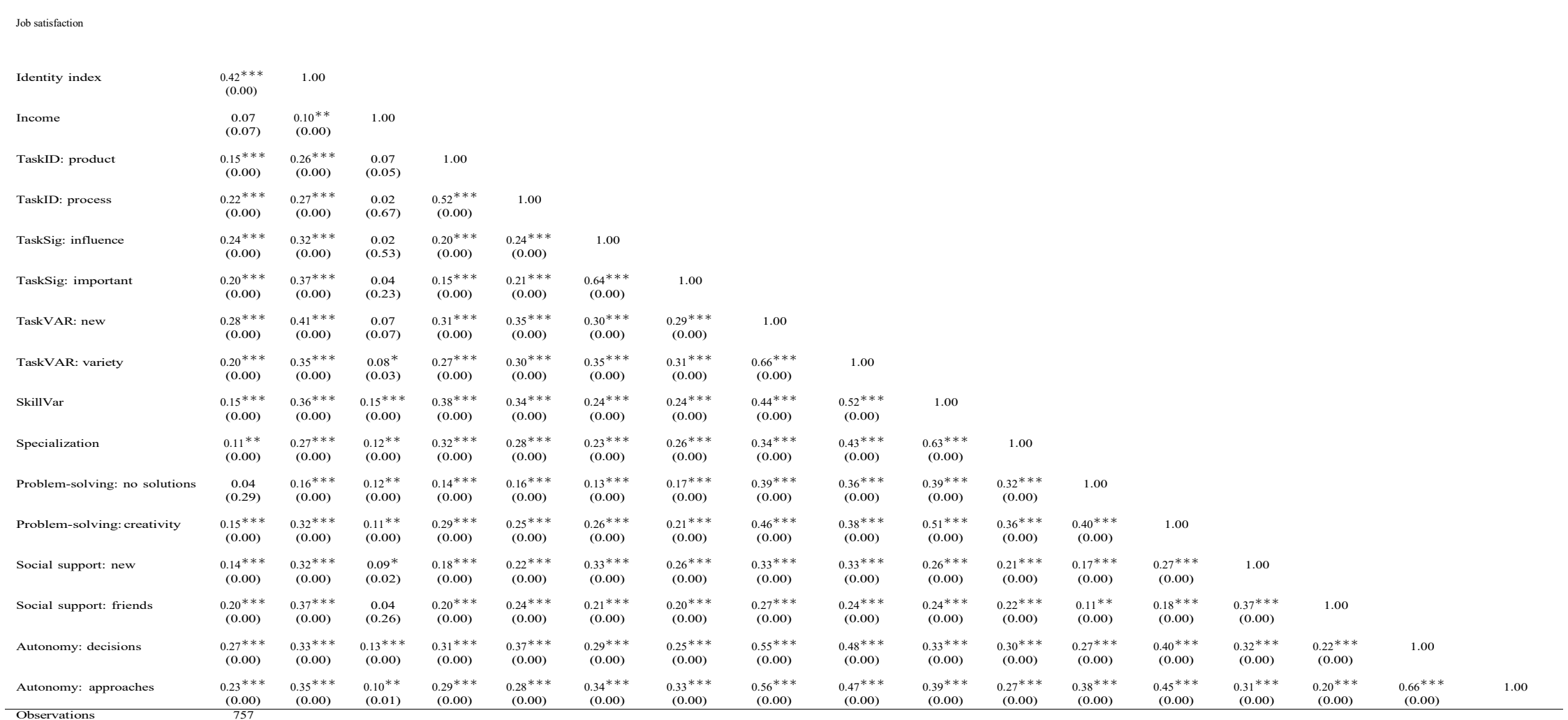

Source: Own data. 
Figure A1: Scree Plot of Confirmatory Factor Analysis Hypothesizing That All Four Identity Variables Load onto One Distinct Factor (i.e., occupational identity).

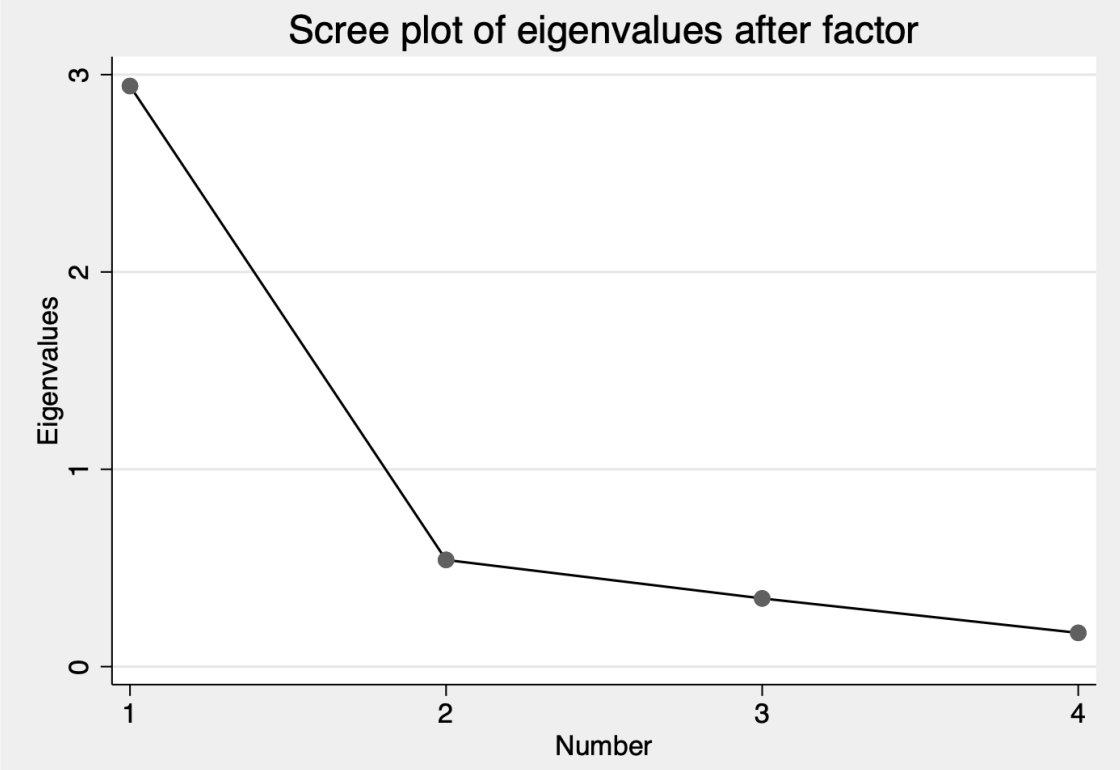

Source: Own data. 
Table A2: Summary Statistics for the Full Sample

\begin{tabular}{|c|c|c|c|}
\hline Job satisfaction & $\frac{\text { mean }}{4.99}$ & $\begin{array}{c}\mathrm{sd} \\
1.63\end{array}$ & $\begin{array}{c}\text { count } \\
1509\end{array}$ \\
\hline \multicolumn{4}{|l|}{ Identity } \\
\hline Identity: part of personality & 6.05 & 1.22 & 1316 \\
\hline Identity: job is my calling & 5.66 & 1.40 & 1296 \\
\hline Identity: proud of my job & 6.19 & 1.12 & 1324 \\
\hline Identity: job is my passion & 5.71 & 1.37 & 1294 \\
\hline Identity index (PCA) & 0.00 & 1.72 & 1282 \\
\hline \multicolumn{4}{|l|}{ Main activity in work (percent) } \\
\hline Admin/Sales & 0.11 & & 1380 \\
\hline Management, no craft & 0.30 & & 1380 \\
\hline Craft, with admin & 0.04 & & 1380 \\
\hline Craft & 0.38 & & 1380 \\
\hline Management, with craft & 0.18 & & 1380 \\
\hline \multicolumn{4}{|l|}{ Vocational development stage (percent) } \\
\hline Apprentice & 0.04 & & 978 \\
\hline Journey(wo)man & 0.19 & & 978 \\
\hline Senior Journey(wo)man & 0.05 & & 978 \\
\hline Master crafts(wo)man & 0.71 & & 978 \\
\hline \multicolumn{4}{|l|}{ WDQ variables } \\
\hline Task identity: complete products/services & 6.02 & 1.21 & 1223 \\
\hline Task identity: complete work process & 5.68 & 1.51 & 1223 \\
\hline Task significance: work has influence on others & 5.58 & 1.28 & 1216 \\
\hline Task significance: work is significant and important & 5.28 & 1.47 & 1211 \\
\hline Task variety: new tasks & 5.92 & 1.17 & 1214 \\
\hline Task variety: variety of tasks & 6.34 & 0.93 & 1211 \\
\hline Skill variety: work requires various skills & 6.30 & 0.86 & 1204 \\
\hline Specialization: work requires specialized skills & 6.03 & 1.07 & 1200 \\
\hline Problem-solving: task with no clear solutions & 5.54 & 1.44 & 1183 \\
\hline Problem-solving: creativity is important for my work & 5.80 & 1.34 & 1191 \\
\hline Social support: meet new people at work & 6.03 & 1.19 & 1264 \\
\hline Social support: colleagues are also friends & 4.52 & 1.64 & 1228 \\
\hline Autonomy: can make many decisions on my own & 6.12 & 1.14 & 1208 \\
\hline Autonomy: abilities allow different approaches & 6.05 & 1.12 & 1209 \\
\hline \multicolumn{4}{|l|}{ Control variables } \\
\hline factors Net income, monthly & 2772.84 & 4220.55 & 951 \\
\hline Income (IHS transformed) & 8.34 & 0.88 & 951 \\
\hline Age & 45.28 & 12.80 & 1086 \\
\hline $\mathrm{Age}^{2}$ & 22.14 & 11.51 & 1086 \\
\hline Gender: female $(0 / 1)$ & 0.17 & & 1090 \\
\hline Hours worked & 48.48 & 13.59 & 1361 \\
\hline Self-employed (0/1) & 0.59 & & 1440 \\
\hline \multicolumn{4}{|l|}{ Full-time (percent) } \\
\hline Full-time & 0.93 & & 1309 \\
\hline Part-time & 0.07 & & 1309 \\
\hline \multicolumn{4}{|l|}{ Firm size (percent) } \\
\hline Solo & 0.08 & & 1928 \\
\hline 2 to 20 & 0.48 & & 1928 \\
\hline 21 to 100 & 0.11 & & 1928 \\
\hline $101+$ & 0.33 & & 1928 \\
\hline \multicolumn{4}{|l|}{ Education, CASMIN Scale (percent) } \\
\hline Primary & 0.13 & & 1098 \\
\hline Secondary & 0.68 & & 1098 \\
\hline Tertiary & 0.19 & & 1098 \\
\hline \multicolumn{4}{|l|}{ Big Five } \\
\hline Big five: extraversion & 15.29 & 3.22 & 1088 \\
\hline Big five: conscientiousness & 17.75 & 2.28 & 1099 \\
\hline Big five: agreeableness & 15.50 & 2.58 & 1092 \\
\hline Big five: openness & 16.01 & 2.98 & 1093 \\
\hline Big five: neuroticism & 11.37 & 3.46 & 1096 \\
\hline Observations & 1930 & & \\
\hline
\end{tabular}

Notes: Containing all observations, where valid responses to a variable were recorded.

Source: Own data. 
Table A3: Subsample Analysis Focusing Solely on Full-time Workers

\begin{tabular}{|c|c|c|c|c|c|c|c|c|}
\hline \multirow{2}{*}{$\begin{array}{l}\text { Identity (Independent variable) } \\
\text { Identity index (pca) }\end{array}$} & \multicolumn{2}{|c|}{$\begin{array}{c}(1) \\
\text { Standard } \\
\end{array}$} & \multicolumn{2}{|c|}{$\begin{array}{c}(2) \\
\text { ID Index }\end{array}$} & \multicolumn{2}{|c|}{$\begin{array}{c}(3) \\
\text { WORK CHAR. }\end{array}$} & \multicolumn{2}{|c|}{$\begin{array}{c}(4) \\
\text { WORK CHAR. + ID }\end{array}$} \\
\hline & & & $0.36^{* * *}$ & $(9.78)$ & & & $0.31 * * *$ & $(7.31)$ \\
\hline $\begin{array}{l}\text { WDQ (Independent variables) } \\
\text { Task identity: complete products/services } \\
\text { Task identity: complete work process } \\
\text { Task significance: work has influence on others } \\
\text { Task significance: work is significant and important } \\
\text { Task variety: new tasks } \\
\text { Task variety: variety of tasks } \\
\text { Skill variety: work requires various skills } \\
\text { Specialization: work requires specialized skills } \\
\text { Problem-solving: task with no clear solutions } \\
\text { Problem-solving: creativity is important for my work } \\
\text { Social support: meet new people at work } \\
\text { Social support: colleagues are also friends } \\
\text { Autonomy: can make many decisions on my own } \\
\text { Autonomy: abilities allow different approaches }\end{array}$ & & & & & $\begin{array}{c}-0.00 \\
0.09^{*} \\
0.19^{* *} \\
-0.00 \\
0.19^{* *} \\
-0.07 \\
0.03 \\
-0.00 \\
-0.07 \\
0.00 \\
-0.07 \\
0.07^{*} \\
0.18^{*} \\
0.00\end{array}$ & $\begin{array}{c}(-0.08) \\
(2.23) \\
(3.01) \\
(-0.01) \\
(2.69) \\
(-0.79) \\
(0.25) \\
(-0.00) \\
(-1.45) \\
(0.04) \\
(-1.29) \\
(2.00) \\
(2.52) \\
(0.03)\end{array}$ & $\begin{array}{c}-0.02 \\
0.09^{*} \\
0.17^{* *} \\
-0.06 \\
0.11 \\
-0.04 \\
-0.06 \\
0.01 \\
-0.05 \\
-0.00 \\
-0.09^{+} \\
0.01 \\
0.16^{*} \\
-0.00\end{array}$ & $\begin{array}{l}(-0.35) \\
(2.25) \\
(3.19) \\
(-1.14) \\
(1.64) \\
(-0.56) \\
(-0.59) \\
(0.23) \\
(-1.09) \\
(-0.01) \\
(-1.81) \\
(0.31) \\
(2.38) \\
(-0.03)\end{array}$ \\
\hline $\begin{array}{l}\text { Simple model: Wage, effort (Indep.Variables) } \\
\text { Income (IHS transformed) } \\
\text { Hours worked } \\
\text { Hours worked x Hours worked }\end{array}$ & $\begin{array}{c}0.18^{+} \\
0.01 \\
-0.00\end{array}$ & $\begin{array}{l}(1.85) \\
(0.19) \\
(-0.63)\end{array}$ & $\begin{array}{r}0.11 \\
-0.01 \\
-0.00\end{array}$ & $\begin{array}{l}(1.24) \\
(-0.31) \\
(-0.14)\end{array}$ & $\begin{array}{l}0.15^{+} \\
-0.00 \\
-0.00\end{array}$ & $\begin{array}{l}(1.69) \\
(-0.08) \\
(-0.33)\end{array}$ & $\begin{array}{l}0.11 \\
-0.01 \\
-0.00\end{array}$ & $\begin{array}{l}(1.32) \\
(-0.26) \\
(-0.20)\end{array}$ \\
\hline $\begin{array}{l}\text { Control variables } \\
\text { Gender: female }(0 / 1) \\
\text { Age } \\
\text { Age }^{2} \\
\text { Self-employed }(0 / 1)\end{array}$ & $\begin{array}{c}0.69 * * * \\
-0.11^{* * *} \\
0.13^{* * *} \\
0.48^{* *}\end{array}$ & $\begin{array}{l}(4.52) \\
(-3.52) \\
(3.76) \\
(2.75)\end{array}$ & $\begin{array}{c}0.59^{* * *} \\
-0.09^{* * *} \\
0.10^{* * *} \\
0.34^{*}\end{array}$ & $\begin{array}{l}(4.06) \\
(-3.33) \\
(3.54) \\
(2.11)\end{array}$ & $\begin{array}{c}0.64^{* * *} \\
-0.10^{* * *} \\
0.12^{* * *} \\
0.29^{+}\end{array}$ & $\begin{array}{l}(4.21) \\
(-3.37) \\
(3.57) \\
(1.70)\end{array}$ & $\begin{array}{c}0.54^{* * *} \\
-0.09^{* *} \\
0.11^{* * *} \\
0.26\end{array}$ & $\begin{array}{l}(3.60) \\
(-3.24) \\
(3.43) \\
(1.59)\end{array}$ \\
\hline $\begin{array}{l}\text { Firm size (base: } 2 \text { to } 20) \text { ) } \\
\text { Solo } \\
21 \text { to } 100 \\
101+\end{array}$ & $\begin{array}{c}0.23 \\
-0.02 \\
0.19\end{array}$ & $\begin{array}{l}(1.00) \\
(-0.11) \\
(0.82)\end{array}$ & $\begin{array}{l}0.26 \\
0.05 \\
0.12\end{array}$ & $\begin{array}{l}(1.16) \\
(0.34) \\
(0.58)\end{array}$ & $\begin{array}{l}0.11 \\
0.03 \\
0.27\end{array}$ & $\begin{array}{l}(0.49) \\
(0.24) \\
(1.22)\end{array}$ & $\begin{array}{l}0.20 \\
0.07 \\
0.20\end{array}$ & $\begin{array}{l}(0.86) \\
(0.52) \\
(0.96)\end{array}$ \\
\hline $\begin{array}{l}\text { Education (CASMIN scale, base: Secondary) } \\
\text { Primary } \\
\text { Tertiary }\end{array}$ & $\begin{array}{l}-0.37 * \\
-0.04\end{array}$ & $\begin{array}{l}(-2.07) \\
(-0.23)\end{array}$ & $\begin{array}{c}-0.31^{+} \\
0.03\end{array}$ & $\begin{array}{l}(-1.85) \\
(0.19)\end{array}$ & $\begin{array}{c}-0.37^{*} \\
-0.06\end{array}$ & $\begin{array}{l}(-2.13) \\
(-0.40)\end{array}$ & $\begin{array}{r}-0.32^{+} \\
0.00\end{array}$ & $\begin{array}{l}(-1.94) \\
(0.02)\end{array}$ \\
\hline $\begin{array}{l}\text { Living (base: Village) } \\
\text { Small town } \\
\text { City } \\
\text { Large city }\end{array}$ & $\begin{array}{r}-0.30^{+} \\
-0.14 \\
-0.08\end{array}$ & $\begin{array}{l}(-1.94) \\
(-0.93) \\
(-0.39)\end{array}$ & $\begin{array}{c}-0.17 \\
-0.08 \\
0.00\end{array}$ & $\begin{array}{l}(-1.16) \\
(-0.58) \\
(0.02)\end{array}$ & $\begin{array}{c}-0.30^{*} \\
0.03 \\
0.02\end{array}$ & $\begin{array}{l}(-1.96) \\
(0.25) \\
(0.09)\end{array}$ & $\begin{array}{l}-0.20 \\
0.01 \\
0.04\end{array}$ & $\begin{array}{l}(-1.33) \\
(0.08) \\
(0.23)\end{array}$ \\
\hline $\begin{array}{l}\text { Personality traits } \\
\text { Big five: extraversion } \\
\text { Big five: conscientiousness } \\
\text { Big five: agreeableness } \\
\text { Big five: openness } \\
\text { Big five: neuroticism }\end{array}$ & $\begin{array}{c}0.05^{* *} \\
0.05^{+} \\
0.03 \\
-0.00 \\
-0.11^{* * *}\end{array}$ & $\begin{array}{l}(2.79) \\
(1.77) \\
(1.11) \\
(-0.22) \\
(-6.15)\end{array}$ & $\begin{array}{c}0.04^{*} \\
0.00 \\
0.01 \\
-0.04^{*} \\
-0.09^{* * *}\end{array}$ & $\begin{array}{l}(2.00) \\
(0.03) \\
(0.65) \\
(-2.14) \\
(-5.86)\end{array}$ & $\begin{array}{c}0.03 \\
0.02 \\
0.01 \\
-0.02 \\
-0.09 * * *\end{array}$ & $\begin{array}{l}(1.57) \\
(0.66) \\
(0.56) \\
(-1.02) \\
(-5.25)\end{array}$ & $\begin{array}{c}0.03 \\
-0.01 \\
0.01 \\
-0.04^{+} \\
-0.09^{* * *}\end{array}$ & $\begin{array}{l}(1.57) \\
(-0.20) \\
(0.46) \\
(-1.83) \\
(-5.36)\end{array}$ \\
\hline Constant & $4.68 * *$ & $(3.28)$ & $7.04^{* * *}$ & $(5.17)$ & $3.40^{*}$ & $(2.41)$ & $5.98^{* * *}$ & (4.29) \\
\hline $\begin{array}{l}\text { Observations } \\
\mathrm{F} \\
\text { Degrees of freedom } \\
\text { Adj. } R^{2}\end{array}$ & $\begin{array}{r}710 \\
9.67 \\
620 \\
0.15\end{array}$ & & $\begin{array}{c}710 \\
14.73 \\
620 \\
0.26\end{array}$ & & $\begin{array}{c}710 \\
10.07 \\
620 \\
0.22\end{array}$ & & $\begin{array}{c}710 \\
11.84 \\
620 \\
0.29\end{array}$ & \\
\hline
\end{tabular}

Notes: OLS regressions with job satisfaction as dependent variable. Model (1) estimates relationship between job satisfaction and income and work effort. Model (2) adds the occupational identity variable as main explanatory variable. Model (3) shows work characteristics as explanatory variables and model (4) presents the relationship between job satisfaction and occupational identity while also controlling for work characteristics. Heteroscedasticity-robust standard errors clustered on the postal code level. Estimation sample kept identical for all models. Unweighted data.

Source: Own data. 
Table A4: Subsample Analysis Focusing Solely on Full-time Workers

\begin{tabular}{|c|c|c|c|c|c|c|c|c|}
\hline \multirow{3}{*}{$\begin{array}{l}\text { DV: Identity Index } \\
\text { WDQ variables (Independent variables) }\end{array}$} & \multicolumn{2}{|c|}{$(1)$} & \multirow{2}{*}{\multicolumn{2}{|c|}{$\begin{array}{c}\text { (2) } \\
\text { WDQ. + TYPE }\end{array}$}} & \multirow{2}{*}{\multicolumn{2}{|c|}{$\begin{array}{c}(3) \\
\text { POSITION }\end{array}$}} & \multirow{2}{*}{\multicolumn{2}{|c|}{$\begin{array}{c}(4) \\
\text { WDQ. }+ \text { POS. }\end{array}$}} \\
\hline & \multicolumn{2}{|c|}{ WORK TYPE } & & & & & & \\
\hline & & & \multirow{2}{*}{\multicolumn{2}{|c|}{$0.04 \quad(074)$}} & & & & \\
\hline Task identity: complete products/services & & & & & & & 0.02 & $(0.33)$ \\
\hline Task identity: complete work process & & & 0.00 & $(0.04)$ & & & -0.01 & $(-0.13)$ \\
\hline Task significance: work has influence on others & & & 0.05 & $(0.72)$ & & & 0.05 & $(0.56)$ \\
\hline Task significance: work is significant and important & & & $0.18^{*}$ & $(2.48)$ & & & $0.14^{+}$ & $(1.66)$ \\
\hline Task variety: new tasks & & & $0.25 * *$ & $(3.18)$ & & & $0.20^{*}$ & $(2.40)$ \\
\hline Task variety: variety of tasks & & & -0.06 & $(-0.66)$ & & & -0.01 & $(-0.12)$ \\
\hline Skill variety: work requires various skills & & & $0.22 *$ & $(2.03)$ & & & $0.27^{*}$ & $(2.14)$ \\
\hline Specialization: work requires specialized skills & & & -0.04 & $(-0.58)$ & & & -0.09 & $(-1.06)$ \\
\hline Problem-solving: task with no clear solutions & & & -0.06 & $(-1.23)$ & & & -0.02 & $(-0.41)$ \\
\hline Problem-solving: creativity is important for my work & & & -0.00 & $(-0.00)$ & & & -0.02 & $(-0.31)$ \\
\hline Social support: meet new people at work & & & 0.07 & $(1.08)$ & & & 0.02 & $(0.27)$ \\
\hline Social support: colleagues are also friends & & & $0.20 * * *$ & $(5.00)$ & & & $0.18^{* * *}$ & $(3.96)$ \\
\hline Autonomy: can make many decisions on my own & & & 0.08 & $(1.06)$ & & & 0.15 & (1.62) \\
\hline Autonomy: abilities allow different approaches & & & 0.03 & $(0.37)$ & & & 0.02 & $(0.26)$ \\
\hline \multicolumn{9}{|l|}{$\begin{array}{l}\text { Control variables in models using WDQ } \\
\text { Main activity at work (base: Craft) }\end{array}$} \\
\hline Admin/Sales & $-0.82 * *$ & $(-2.94)$ & $-0.56^{*}$ & $(-2.21)$ & & & $-0.50^{+}$ & $(-1.66)$ \\
\hline Management, no craft & -0.01 & $(-0.05)$ & -0.18 & $(-1.12)$ & & & -0.02 & $(-0.13)$ \\
\hline Craft, with admin & -0.21 & $(-0.60)$ & -0.09 & $(-0.30)$ & & & -0.09 & $(-0.30)$ \\
\hline Management, with craft & 0.25 & $(1.37)$ & 0.11 & $(0.67)$ & & & 0.06 & $(0.34)$ \\
\hline \multicolumn{9}{|l|}{ Vocational development stage (base: Master crafter) } \\
\hline Apprentice & & & & & $-1.44^{* *}$ & $(-2.69)$ & $-1.04^{*}$ & $(-2.45)$ \\
\hline Journey(wo)man & & & & & -0.39 & $(-1.60)$ & -0.19 & $(-0.79)$ \\
\hline Senior Journey(wo)man & & & & & 0.05 & $(0.19)$ & -0.07 & $(-0.30)$ \\
\hline \multicolumn{9}{|l|}{ Control variables } \\
\hline Income (IHS transformed) & & & 0.15 & $(1.59)$ & & & 0.05 & $(0.57)$ \\
\hline Gender: female $(0 / 1)$ & $0.29 *$ & $(2.00)$ & $0.34^{*}$ & $(2.37)$ & $0.31^{+}$ & $(1.73)$ & $0.36^{*}$ & $(2.09)$ \\
\hline Age & -0.03 & $(-0.87)$ & -0.03 & $(-0.84)$ & $-0.09^{+}$ & $(-1.91)$ & -0.06 & $(-1.43)$ \\
\hline $\mathrm{Age}^{2}$ & 0.05 & $(1.12)$ & 0.04 & $(0.98)$ & $0.09^{+}$ & $(1.95)$ & 0.07 & $(1.55)$ \\
\hline Self-employed $(0 / 1)$ & $0.35^{*}$ & $(2.03)$ & 0.12 & $(0.73)$ & $0.51^{*}$ & $(2.29)$ & 0.14 & $(0.64)$ \\
\hline \multicolumn{9}{|l|}{ Firm size (base: 2 to 20 )) } \\
\hline Solo & -0.20 & $(-0.69)$ & -0.36 & $(-1.34)$ & -0.22 & $(-0.72)$ & -0.40 & $(-1.20)$ \\
\hline 21 to 100 & -0.08 & $(-0.45)$ & -0.08 & $(-0.51)$ & 0.03 & $(0.14)$ & 0.02 & $(0.09)$ \\
\hline $101+$ & 0.27 & $(1.31)$ & 0.25 & $(1.29)$ & 0.29 & $(1.25)$ & $0.39^{+}$ & $(1.86)$ \\
\hline \multicolumn{9}{|l|}{ Education (CASMIN scale, base: Secondary) } \\
\hline Primary & -0.25 & $(-1.38)$ & -0.20 & $(-1.22)$ & -0.22 & $(-1.07)$ & -0.19 & $(-1.05)$ \\
\hline Tertiary & -0.19 & $(-1.09)$ & -0.19 & $(-1.25)$ & -0.15 & $(-0.66)$ & -0.22 & $(-1.11)$ \\
\hline \multicolumn{9}{|l|}{ Living (base: Village) } \\
\hline Small town & $-0.34^{*}$ & $(-2.25)$ & $-0.33^{*}$ & $(-2.32)$ & -0.18 & $(-1.13)$ & -0.18 & $(-1.22)$ \\
\hline City & -0.16 & $(-1.06)$ & 0.07 & $(0.45)$ & $-0.35^{+}$ & $(-1.96)$ & -0.09 & $(-0.55)$ \\
\hline Large city & -0.21 & $(-0.93)$ & -0.10 & $(-0.50)$ & -0.23 & $(-0.89)$ & -0.16 & $(-0.67)$ \\
\hline \multicolumn{9}{|l|}{ Personality traits } \\
\hline Big five: extraversion & $0.05^{*}$ & $(2.27)$ & 0.00 & $(0.19)$ & $0.08 * *$ & $(3.13)$ & 0.04 & $(1.59)$ \\
\hline Big five: conscientiousness & $0.12 * * *$ & $(3.40)$ & $0.07^{+}$ & $(1.96)$ & $0.09^{*}$ & $(2.21)$ & 0.04 & $(0.93)$ \\
\hline Big five: agreeableness & 0.03 & $(1.40)$ & 0.01 & $(0.46)$ & 0.04 & $(1.39)$ & 0.02 & $(0.74)$ \\
\hline Big five: openness & $0.09^{* * *}$ & $(3.87)$ & $0.05^{*}$ & $(2.25)$ & $0.09^{* *}$ & $(3.12)$ & $0.05^{+}$ & $(1.85)$ \\
\hline Big five: neuroticism & $-0.05^{*}$ & $(-2.52)$ & -0.03 & $(-1.34)$ & $-0.04^{+}$ & $(-1.81)$ & -0.02 & $(-1.02)$ \\
\hline Constant & $-3.72 * * *$ & $(-3.48)$ & $-7.82 * * *$ & $(-6.08)$ & $-2.44^{*}$ & $(-1.98)$ & $-6.08 * * *$ & $(-4.18)$ \\
\hline Observations & 710 & & 710 & & 536 & & 536 & \\
\hline $\mathrm{F}$ & 7.48 & & 10.47 & & 6.22 & & 8.15 & \\
\hline Degrees of freedom & 620 & & 620 & & 480 & & 480 & \\
\hline Adj. $R^{2}$ & 0.17 & & 0.34 & & 0.20 & & 0.33 & \\
\hline
\end{tabular}

$t$ statistics in parentheses

${ }^{+} p<0.10,{ }^{*} p<0.05,{ }^{* *} p<0.01,{ }^{* * *} p<0.001$

Notes: OLS regressions with occupational identity index as dependent variable. Model (1) analyses the relationship between occupational identity and main activity at work, model (2) between occupational identity and work characteristics. Models (3) and (4) repeat this analysis with focus on the relationship between occupational identity and vocational position. Heteroscedasticity-robust standard errors clustered on the postal code level. Estimation sample kept identical in models (1) and (2) but is lower for models (3) and (4) due to missing data concerning vocational position. Unweighted data.

Source: Own data. 
Table A5: Tobit Regressions with Job Satisfaction as Dependent Variable

\begin{tabular}{|c|c|c|c|c|c|c|c|c|}
\hline \multirow[b]{2}{*}{$\begin{array}{l}\text { Identity (Independent variable) } \\
\text { Identity index (pca) }\end{array}$} & \multicolumn{2}{|c|}{$\begin{array}{c}(1) \\
\text { Standard } \\
\end{array}$} & \multicolumn{2}{|c|}{$\begin{array}{c}(2) \\
\text { ID Index }\end{array}$} & \multicolumn{2}{|c|}{$\begin{array}{c}(3) \\
\text { WORK CHAR. }\end{array}$} & \multicolumn{2}{|c|}{$\begin{array}{c}(4) \\
\text { WORK CHAR. + ID }\end{array}$} \\
\hline & & & $0.39 * * *$ & $(9.84)$ & & & $0.32 * * *$ & (7.18) \\
\hline $\begin{array}{l}\text { WDQ (Independent variables) } \\
\text { Task identity: complete products/services } \\
\text { Task identity: complete work process } \\
\text { Task significance: work has influence on others } \\
\text { Task significance: work is significant and important } \\
\text { Task variety: new tasks } \\
\text { Task variety: variety of tasks } \\
\text { Skill variety: work requires various skills } \\
\text { Specialization: work requires specialized skills } \\
\text { Problem-solving: task with no clear solutions } \\
\text { Problem-solving: creativity is important for my work } \\
\text { Social support: meet new people at work } \\
\text { Social support: colleagues are also friends } \\
\text { Autonomy: can make many decisions on my own } \\
\text { Autonomy: abilities allow different approaches }\end{array}$ & & & & & $\begin{array}{c}-0.02 \\
0.11^{* *} \\
0.19^{* *} \\
0.02 \\
0.21^{* *} \\
-0.07 \\
0.07 \\
-0.02 \\
-0.09 \\
-0.01 \\
-0.09 \\
0.10^{*} \\
0.16^{*} \\
0.01\end{array}$ & $\begin{array}{c}(-0.31) \\
(2.59) \\
(2.94) \\
(0.33) \\
(2.94) \\
(-0.76) \\
(0.66) \\
(-0.27) \\
(-1.59) \\
(-0.14) \\
(-1.55) \\
(2.43) \\
(2.05) \\
(0.08)\end{array}$ & $\begin{array}{c}-0.03 \\
0.10^{*} \\
0.19^{*} \\
-0.05 \\
0.15^{*} \\
-0.07 \\
-0.01 \\
0.00 \\
-0.07 \\
-0.02 \\
-0.11^{*} \\
0.03 \\
0.13^{+} \\
-0.00\end{array}$ & $\begin{array}{c}(-0.58) \\
(2.57) \\
(3.26) \\
(-0.92) \\
(2.04) \\
(-0.84) \\
(-0.05) \\
(0.01) \\
(-1.26) \\
(-0.28) \\
(-2.04) \\
(0.87) \\
(1.83) \\
(-0.04)\end{array}$ \\
\hline $\begin{array}{l}\text { Simple model: Wage, effort (Indep.Variables) } \\
\text { Income (IHS transformed) } \\
\text { Part-time } \\
\text { Hours worked } \\
\text { Hours worked x Hours worked }\end{array}$ & $\begin{array}{c}0.16 \\
-0.58^{+} \\
-0.01 \\
-0.00\end{array}$ & $\begin{array}{l}(1.49) \\
(-1.68) \\
(-0.46) \\
(-0.03)\end{array}$ & $\begin{array}{r}0.09 \\
-0.39 \\
-0.02 \\
0.00\end{array}$ & $\begin{array}{c}(0.84) \\
(-1.04) \\
(-0.80) \\
(0.30)\end{array}$ & $\begin{array}{c}0.14 \\
-0.66^{+} \\
-0.02 \\
0.00\end{array}$ & $\begin{array}{l}(1.42) \\
(-1.82) \\
(-0.70) \\
(0.24)\end{array}$ & $\begin{array}{r}0.10 \\
-0.53 \\
-0.02 \\
0.00\end{array}$ & $\begin{array}{c}(1.01) \\
(-1.41) \\
(-0.81) \\
(0.31)\end{array}$ \\
\hline $\begin{array}{l}\text { Control variables } \\
\text { Gender: female }(0 / 1) \\
\text { Age } \\
\text { Age }^{2} \\
\text { Self-employed }(0 / 1)\end{array}$ & $\begin{array}{c}0.79^{* * *} \\
-0.15^{* * *} \\
0.18^{* * *} \\
0.58^{* *}\end{array}$ & $\begin{array}{l}(4.56) \\
(-4.23) \\
(4.50) \\
(3.14)\end{array}$ & $\begin{array}{c}0.68^{* * *} \\
-0.13 * * * \\
0.15^{* * *} \\
0.41^{*}\end{array}$ & $\begin{array}{l}(4.06) \\
(-3.97) \\
(4.22) \\
(2.41)\end{array}$ & $\begin{array}{c}0.77^{* * *} \\
-0.14^{* * *} \\
0.16^{* * *} \\
0.37^{*}\end{array}$ & $\begin{array}{l}(4.51) \\
(-3.86) \\
(4.11) \\
(2.06)\end{array}$ & $\begin{array}{c}0.65^{* * *} \\
-0.12^{* * *} \\
0.15^{* * *} \\
0.34^{+}\end{array}$ & $\begin{array}{c}(3.86) \\
(-3.68) \\
(3.93) \\
(1.93)\end{array}$ \\
\hline $\begin{array}{l}\text { Firm size (base: } 2 \text { to } 20 \text { )) } \\
\text { Solo } \\
21 \text { to } 100 \\
101+\end{array}$ & $\begin{array}{r}0.33 \\
-0.05 \\
0.19\end{array}$ & $\begin{array}{l}(1.29) \\
(-0.30) \\
(0.76)\end{array}$ & $\begin{array}{l}0.33 \\
0.02 \\
0.19\end{array}$ & $\begin{array}{l}(1.27) \\
(0.15) \\
(0.82)\end{array}$ & $\begin{array}{l}0.18 \\
0.02 \\
0.33\end{array}$ & $\begin{array}{l}(0.72) \\
(0.13) \\
(1.33)\end{array}$ & $\begin{array}{l}0.24 \\
0.06 \\
0.30\end{array}$ & $\begin{array}{l}(0.95) \\
(0.43) \\
(1.27)\end{array}$ \\
\hline $\begin{array}{l}\text { Education (CASMIN scale, base: Secondary) } \\
\text { Primary } \\
\text { Tertiary }\end{array}$ & $\begin{array}{c}-0.43^{*} \\
-0.07\end{array}$ & $\begin{array}{l}(-2.22) \\
(-0.38)\end{array}$ & $\begin{array}{c}-0.34^{+} \\
0.02\end{array}$ & $\begin{array}{l}(-1.90) \\
(0.13)\end{array}$ & $\begin{array}{l}-0.44^{*} \\
-0.07\end{array}$ & $\begin{array}{l}(-2.38) \\
(-0.43)\end{array}$ & $\begin{array}{c}-0.37^{*} \\
0.01\end{array}$ & $\begin{array}{c}(-2.12) \\
(0.04)\end{array}$ \\
\hline $\begin{array}{l}\text { Living (base: Village) } \\
\text { Small town } \\
\text { City } \\
\text { Large city }\end{array}$ & $\begin{array}{l}-0.37^{*} \\
-0.17 \\
-0.07\end{array}$ & $\begin{array}{l}(-2.18) \\
(-1.00) \\
(-0.31)\end{array}$ & $\begin{array}{r}-0.24 \\
-0.10 \\
0.06\end{array}$ & $\begin{array}{l}(-1.47) \\
(-0.65) \\
(0.27)\end{array}$ & $\begin{array}{c}-0.37^{*} \\
0.03 \\
0.05\end{array}$ & $\begin{array}{l}(-2.23) \\
(0.21) \\
(0.25)\end{array}$ & $\begin{array}{r}-0.27^{+} \\
0.01 \\
0.11\end{array}$ & $\begin{array}{l}(-1.68) \\
(0.09) \\
(0.52)\end{array}$ \\
\hline $\begin{array}{l}\text { Personality traits } \\
\text { Big five: extraversion } \\
\text { Big five: conscientiousness } \\
\text { Big five: agreeableness } \\
\text { Big five: openness } \\
\text { Big five: neuroticism }\end{array}$ & $\begin{array}{c}0.07^{* *} \\
0.08^{*} \\
0.03 \\
-0.00 \\
-0.13^{* * *}\end{array}$ & $\begin{array}{l}(3.13) \\
(2.41) \\
(0.98) \\
(-0.13) \\
(-6.65)\end{array}$ & $\begin{array}{c}0.05^{*} \\
0.02 \\
0.01 \\
-0.04^{*} \\
-0.12^{* * *}\end{array}$ & $\begin{array}{l}(2.29) \\
(0.55) \\
(0.58) \\
(-2.03) \\
(-6.39)\end{array}$ & $\begin{array}{c}0.04^{+} \\
0.03 \\
0.01 \\
-0.02 \\
-0.12^{* * *}\end{array}$ & $\begin{array}{l}(1.82) \\
(1.10) \\
(0.49) \\
(-0.89) \\
(-5.89)\end{array}$ & $\begin{array}{c}0.04^{+} \\
0.01 \\
0.01 \\
-0.04^{+} \\
-0.11^{*} * *\end{array}$ & $\begin{array}{c}(1.80) \\
(0.24) \\
(0.44) \\
(-1.73) \\
(-5.94)\end{array}$ \\
\hline Constant & $5.75^{* * *}$ & $(4.01)$ & $8.08^{* * *}$ & $(5.87)$ & $4.12 * *$ & $(3.06)$ & $6.81^{* * *}$ & $(4.98)$ \\
\hline $\operatorname{var(e.jobsat)}$ & $2.86^{* * *}$ & (16.18) & $2.49 * * *$ & (14.31) & $2.56^{* * *}$ & (15.29) & $2.36^{* * *}$ & $(14.16)$ \\
\hline $\begin{array}{l}\text { Observations } \\
\text { F } \\
\text { Degrees of freedoM }\end{array}$ & $\begin{array}{c}757 \\
8.92 \\
736\end{array}$ & & $\begin{array}{c}757 \\
13.40 \\
735\end{array}$ & & $\begin{array}{c}757 \\
9.48 \\
722\end{array}$ & & $\begin{array}{c}757 \\
10.84 \\
721\end{array}$ & \\
\hline
\end{tabular}

Notes: Model (1) estimates relationship between job satisfaction and income and work effort. Model (2) adds the occupational identity variable as main explanatory variable. Model (3) shows work characteristics as explanatory variables and model (4) presents the relationship between job satisfaction and occupational identity while also controlling for work characteristics. Heteroscedasticity-robust standard errors clustered on the postal code level. Estimation sample kept identical for all models. Unweighted data.

Source: Own data. 
Table A6: Tobit Regressions with Occupational Identity Index as Dependent Variable

\begin{tabular}{|c|c|c|c|c|c|c|c|c|}
\hline \multirow{2}{*}{$\begin{array}{l}\text { DV: Identity Index } \\
\text { WDQ variables (Independent variables) }\end{array}$} & \multicolumn{2}{|c|}{$(1)$} & \multicolumn{2}{|c|}{$\begin{array}{c}(2) \\
\text { WDQ.+TYPE }\end{array}$} & \multicolumn{2}{|c|}{$\begin{array}{c}(3) \\
\text { POSITION }\end{array}$} & \multicolumn{2}{|c|}{$\begin{array}{c}(4) \\
\text { WDQ. + POS. }\end{array}$} \\
\hline & & & & & \multirow[b]{2}{*}{0.07} & \multirow[b]{2}{*}{$(0.91)$} \\
\hline Task identity: complete products/services & & & 0.06 & $(0.99)$ & & & & \\
\hline Task identity: complete work process & & & -0.01 & $(-0.14)$ & & & -0.05 & $(-0.77)$ \\
\hline Task significance: work has influence on others & & & 0.01 & $(0.18)$ & & & 0.01 & $(0.14)$ \\
\hline Task significance: work is significant and important & & & $0.24 * *$ & $(3.22)$ & & & $0.20^{*}$ & $(2.18)$ \\
\hline Task variety: new tasks & & & $0.23 * *$ & $(2.77)$ & & & $0.21^{*}$ & $(2.32)$ \\
\hline Task variety: variety of tasks & & & 0.00 & $(0.05)$ & & & 0.03 & $(0.23)$ \\
\hline Skill variety: work requires various skills & & & $0.22^{+}$ & $(1.95)$ & & & $0.27^{*}$ & $(2.04)$ \\
\hline Specialization: work requires specialized skills & & & -0.04 & $(-0.44)$ & & & -0.07 & $(-0.76)$ \\
\hline Problem-solving: task with no clear solutions & & & -0.03 & $(-0.55)$ & & & 0.01 & $(0.09)$ \\
\hline Problem-solving: creativity is important for my work & & & 0.02 & $(0.38)$ & & & -0.03 & $(-0.36)$ \\
\hline Social support: meet new people at work & & & 0.09 & $(1.35)$ & & & 0.02 & $(0.32)$ \\
\hline Social support: colleagues are also friends & & & $0.23 * * *$ & $(5.25)$ & & & $0.23^{* * *}$ & (4.39) \\
\hline Autonomy: can make many decisions on my own & & & 0.05 & $(0.64)$ & & & 0.12 & (1.19) \\
\hline Autonomy: abilities allow different approaches & & & 0.08 & $(0.97)$ & & & 0.03 & $(0.32)$ \\
\hline \multicolumn{9}{|l|}{ Control variables in models using WDQ } \\
\hline Admin/Sales & $-0.87 * *$ & $(-3.17)$ & $-0.53 *$ & $(-2.14)$ & & & $-0.65 *$ & $(-2.02)$ \\
\hline Management, no craft & 0.05 & $(0.22)$ & -0.15 & $(-0.80)$ & & & -0.07 & $(-0.33)$ \\
\hline Craft, with admin & -0.13 & $(-0.31)$ & 0.00 & $(0.01)$ & & & 0.03 & $(0.08)$ \\
\hline Management, with craft & $0.45^{+}$ & $(1.91)$ & 0.27 & $(1.28)$ & & & 0.23 & $(0.96)$ \\
\hline \multicolumn{9}{|l|}{ Vocational development stage (base: Master crafter) } \\
\hline Apprentice & & & & & $-1.50^{* *}$ & $(-2.67)$ & $-1.02 *$ & $(-2.27)$ \\
\hline Journey(wo)man & & & & & -0.39 & $(-1.51)$ & -0.13 & $(-0.52)$ \\
\hline Senior Journey(wo)man & & & & & -0.06 & $(-0.23)$ & -0.23 & $(-0.88)$ \\
\hline \multicolumn{9}{|l|}{ Control variables } \\
\hline Income (IHS transformed) & & & $0.21^{+}$ & $(1.95)$ & & & 0.07 & $(0.54)$ \\
\hline Gender: female $(0 / 1)$ & $0.38^{*}$ & (1.99) & $0.55^{* *}$ & $(3.00)$ & $0.49^{*}$ & $(2.16)$ & $0.62 * *$ & $(2.77)$ \\
\hline Age & $-0.08^{+}$ & $(-1.86)$ & $-0.07^{+}$ & $(-1.78)$ & $-0.13 *$ & $(-2.37)$ & $-0.09^{+}$ & $(-1.84)$ \\
\hline $\mathrm{Age}^{2}$ & $0.10^{*}$ & $(2.05)$ & $0.08^{+}$ & $(1.88)$ & $0.14^{*}$ & $(2.43)$ & $0.11^{*}$ & $(2.02)$ \\
\hline Self-employed $(0 / 1)$ & $0.56^{* *}$ & (2.63) & 0.22 & $(1.17)$ & $0.73^{* *}$ & $(2.86)$ & 0.29 & (1.13) \\
\hline \multicolumn{9}{|l|}{ Firm size (base: 2 to 20 )) } \\
\hline Solo & -0.04 & $(-0.13)$ & -0.26 & $(-0.94)$ & -0.20 & $(-0.56)$ & -0.37 & $(-1.03)$ \\
\hline 21 to 100 & 0.01 & $(0.06)$ & -0.05 & $(-0.27)$ & 0.06 & $(0.27)$ & 0.05 & $(0.24)$ \\
\hline $101+$ & 0.17 & $(0.64)$ & 0.16 & $(0.67)$ & 0.27 & $(1.02)$ & $0.46^{*}$ & (1.98) \\
\hline \multicolumn{9}{|l|}{ Education (CASMIN scale, base: Secondary) } \\
\hline Primary & -0.23 & $(-1.01)$ & -0.13 & $(-0.68)$ & -0.08 & $(-0.35)$ & -0.06 & $(-0.30)$ \\
\hline Tertiary & -0.25 & $(-1.26)$ & -0.24 & $(-1.37)$ & -0.10 & $(-0.38)$ & -0.20 & $(-0.84)$ \\
\hline \multicolumn{9}{|l|}{ Living (base: Village) } \\
\hline Small town & $-0.39^{*}$ & $(-2.10)$ & $-0.36^{*}$ & $(-2.14)$ & -0.21 & $(-1.06)$ & -0.20 & $(-1.13)$ \\
\hline City & $-0.29^{+}$ & $(-1.65)$ & -0.04 & $(-0.26)$ & $-0.47^{*}$ & $(-2.34)$ & -0.16 & $(-0.86)$ \\
\hline Large city & -0.41 & $(-1.50)$ & -0.26 & $(-1.12)$ & -0.31 & $(-1.04)$ & -0.25 & $(-0.91)$ \\
\hline \multicolumn{9}{|l|}{ Personality traits } \\
\hline Big five: extraversion & $0.06^{*}$ & $(2.50)$ & 0.01 & $(0.32)$ & $0.10^{* * *}$ & $(3.31)$ & $0.05^{+}$ & (1.78) \\
\hline Big five: conscientiousness & $0.18^{* * *}$ & $(4.70)$ & $0.11^{* *}$ & $(2.95)$ & $0.14^{* *}$ & $(3.02)$ & $0.08^{+}$ & $(1.79)$ \\
\hline Big five: agreeableness & 0.04 & $(1.25)$ & 0.01 & $(0.42)$ & 0.04 & $(1.22)$ & 0.02 & $(0.70)$ \\
\hline Big five: openness & $0.12^{* * *}$ & $(4.44)$ & $0.07^{* *}$ & $(2.62)$ & $0.12 * * *$ & $(3.59)$ & $0.07^{*}$ & $(2.33)$ \\
\hline Big five: neuroticism & $-0.07 * *$ & $(-2.90)$ & $-0.04^{+}$ & $(-1.95)$ & $-0.06^{*}$ & $(-2.24)$ & -0.04 & $(-1.59)$ \\
\hline Constant & $-4.28 * * *$ & $(-3.54)$ & $-9.50 * * *$ & $(-7.02)$ & $-2.99^{*}$ & $(-2.08)$ & $-7.51 * * *$ & $(-4.25)$ \\
\hline var(e.identity) & $3.35^{* * *}$ & $(12.15)$ & $2.54 * * *$ & (12.13) & $3.06^{* * *}$ & $(10.37)$ & $2.41^{* * *}$ & (9.89) \\
\hline Observations & 757 & & 757 & & 559 & & 559 & \\
\hline F & 7.99 & & 10.98 & & 6.59 & & 8.26 & \\
\hline Degrees of freedom & 736 & & 721 & & 539 & & 520 & \\
\hline
\end{tabular}

Notes: Model (1) analyzes the relationship between occupational identity and main activity at work, model (2) between occupational identity and work characteristics. Models (3) and (4) repeat this analysis with focus on the relationship between occupational identity and vocational position. Heteroscedasticity-robust standard errors clustered on the postal code level. Estimation sample kept identical in models (1) and (2) but is lower for models (3) and (4) due to missing data concerning occupational position. Unweighted data.

Source: Own data. 
Table A7: Ordered Probit Regressions with Job Satisfaction as Dependent Variable

\begin{tabular}{|c|c|c|c|c|c|c|c|c|}
\hline \multirow{2}{*}{$\begin{array}{l}\text { Identity (Independent variable) } \\
\text { Identity index (pca) }\end{array}$} & \multicolumn{2}{|c|}{$\begin{array}{c}(1) \\
\text { Standard } \\
\end{array}$} & \multicolumn{2}{|c|}{$\begin{array}{c}(2) \\
\text { ID Index } \\
\end{array}$} & \multicolumn{2}{|c|}{$\begin{array}{c}(3) \\
\text { WORK CHAR. }\end{array}$} & \multicolumn{2}{|c|}{$\begin{array}{c}(4) \\
\text { WORK CHAR. + ID }\end{array}$} \\
\hline & & & $0.25^{* * *}$ & $(8.62)$ & & & $0.21^{* * *}$ & $(6.60)$ \\
\hline $\begin{array}{l}\text { WDQ (Independent variables) } \\
\text { Task identity: complete products/services } \\
\text { Task identity: complete work process } \\
\text { Task significance: work has influence on others } \\
\text { Task significance: work is significant and important } \\
\text { Task variety: new tasks } \\
\text { Task variety: variety of tasks } \\
\text { Skill variety: work requires various skills } \\
\text { Specialization: work requires specialized skills } \\
\text { Problem-solving: task with no clear solutions } \\
\text { Problem-solving: creativity is important for my work } \\
\text { Social support: meet new people at work } \\
\text { Social support: colleagues are also friends } \\
\text { Autonomy: can make many decisions on my own } \\
\text { Autonomy: abilities allow different approaches }\end{array}$ & & & & & $\begin{array}{c}-0.00 \\
0.07^{*} \\
0.12^{* *} \\
0.01 \\
0.14^{* *} \\
-0.04 \\
0.05 \\
-0.01 \\
-0.06^{+} \\
0.00 \\
-0.06 \\
0.07^{* *} \\
0.10^{*} \\
0.00\end{array}$ & $\begin{array}{c}(-0.06) \\
(2.49) \\
(2.95) \\
(0.38) \\
(3.00) \\
(-0.72) \\
(0.64) \\
(-0.31) \\
(-1.72) \\
(0.04) \\
(-1.64) \\
(2.59) \\
(2.10) \\
(0.03)\end{array}$ & $\begin{array}{c}-0.01 \\
0.07^{*} \\
0.13^{* *} \\
-0.03 \\
0.10^{*} \\
-0.05 \\
-0.00 \\
-0.00 \\
-0.05 \\
-0.00 \\
-0.08^{*} \\
0.03 \\
0.09^{+} \\
-0.00\end{array}$ & $\begin{array}{l}(-0.34) \\
(2.49) \\
(3.24) \\
(-0.85) \\
(2.15) \\
(-0.81) \\
(-0.06) \\
(-0.07) \\
(-1.38) \\
(-0.10) \\
(-2.13) \\
(1.04) \\
(1.87) \\
(-0.07)\end{array}$ \\
\hline $\begin{array}{l}\text { Simple model: Wage, effort (Indep.Variables) } \\
\text { Income (IHS transformed) } \\
\text { Part-time } \\
\text { Hours worked } \\
\text { Hours worked x Hours worked }\end{array}$ & $\begin{array}{c}0.09 \\
-0.37^{+} \\
-0.01 \\
0.00\end{array}$ & $\begin{array}{c}(1.42) \\
(-1.82) \\
(-0.51) \\
(0.01)\end{array}$ & $\begin{array}{c}0.05 \\
-0.27 \\
-0.01 \\
0.00\end{array}$ & $\begin{array}{c}(0.79) \\
(-1.16) \\
(-0.86) \\
(0.34)\end{array}$ & $\begin{array}{c}0.09 \\
-0.44^{+} \\
-0.01 \\
0.00\end{array}$ & $\begin{array}{l}(1.36) \\
(-1.94) \\
(-0.76) \\
(0.28)\end{array}$ & $\begin{array}{c}0.06 \\
-0.37 \\
-0.01 \\
0.00\end{array}$ & $\begin{array}{l}(0.96) \\
(-1.52) \\
(-0.87) \\
(0.35)\end{array}$ \\
\hline $\begin{array}{l}\text { Control variables } \\
\text { Gender: female }(0 / 1) \\
\text { Age } \\
\text { Age }^{2} \\
\text { Self-employed }(0 / 1)\end{array}$ & $\begin{array}{c}0.48^{* * *} \\
-0.09^{* * *} \\
0.11^{* * *} \\
0.35^{* *}\end{array}$ & $\begin{array}{l}(4.43) \\
(-4.24) \\
(4.56) \\
(3.07)\end{array}$ & $\begin{array}{c}0.44^{* * *} \\
-0.08^{* * *} \\
0.10^{* * *} \\
0.26^{*}\end{array}$ & $\begin{array}{l}(3.97) \\
(-3.91) \\
(4.21) \\
(2.35)\end{array}$ & $\begin{array}{c}0.49^{* * *} \\
-0.09^{* * *} \\
0.10^{* * *} \\
0.23^{*}\end{array}$ & $\begin{array}{l}(4.39) \\
(-3.83) \\
(4.12) \\
(1.98)\end{array}$ & $\begin{array}{c}0.43^{* * *} \\
-0.08^{* * *} \\
0.10^{* * *} \\
0.22^{+}\end{array}$ & $\begin{array}{l}(3.78) \\
(-3.59) \\
(3.89) \\
(1.85)\end{array}$ \\
\hline $\begin{array}{l}\text { Firm size (base: } 2 \text { to } 20) \text { ) } \\
\text { Solo } \\
21 \text { to } 100 \\
101+\end{array}$ & $\begin{array}{c}0.21 \\
-0.05 \\
0.09\end{array}$ & $\begin{array}{c}(1.35) \\
(-0.51) \\
(0.58)\end{array}$ & $\begin{array}{c}0.22 \\
-0.01 \\
0.10\end{array}$ & $\begin{array}{c}(1.30) \\
(-0.11) \\
(0.61)\end{array}$ & $\begin{array}{c}0.12 \\
-0.01 \\
0.18\end{array}$ & $\begin{array}{c}(0.77) \\
(-0.10) \\
(1.11)\end{array}$ & $\begin{array}{l}0.16 \\
0.02 \\
0.17\end{array}$ & $\begin{array}{l}(0.97) \\
(0.17) \\
(1.04)\end{array}$ \\
\hline $\begin{array}{l}\text { Education (CASMIN scale, base: Secondary) } \\
\text { Primary } \\
\text { Tertiary }\end{array}$ & $\begin{array}{c}-0.27^{*} \\
-0.04\end{array}$ & $\begin{array}{l}(-2.35) \\
(-0.36)\end{array}$ & $\begin{array}{c}-0.23^{*} \\
0.02\end{array}$ & $\begin{array}{l}(-2.02) \\
(0.14)\end{array}$ & $\begin{array}{l}-0.29^{*} \\
-0.05\end{array}$ & $\begin{array}{l}(-2.52) \\
(-0.41)\end{array}$ & $\begin{array}{c}-0.26^{*} \\
0.01\end{array}$ & $\begin{array}{r}(-2.26) \\
(0.05)\end{array}$ \\
\hline $\begin{array}{l}\text { Living (base: Village) } \\
\text { Small town } \\
\text { City } \\
\text { Large city }\end{array}$ & $\begin{array}{l}-0.24^{*} \\
-0.10 \\
-0.03\end{array}$ & $\begin{array}{l}(-2.31) \\
(-0.96) \\
(-0.26)\end{array}$ & $\begin{array}{c}-0.17 \\
-0.06 \\
0.04\end{array}$ & $\begin{array}{l}(-1.59) \\
(-0.65) \\
(0.32)\end{array}$ & $\begin{array}{c}-0.25^{*} \\
0.02 \\
0.05\end{array}$ & $\begin{array}{l}(-2.36) \\
(0.24) \\
(0.33)\end{array}$ & $\begin{array}{r}-0.20^{+} \\
0.01 \\
0.08\end{array}$ & $\begin{array}{l}(-1.81) \\
(0.11) \\
(0.60)\end{array}$ \\
\hline $\begin{array}{l}\text { Personality traits } \\
\text { Big five: extraversion } \\
\text { Big five: conscientiousness } \\
\text { Big five: agreeableness } \\
\text { Big five: openness } \\
\text { Big five: neuroticism }\end{array}$ & $\begin{array}{c}0.04^{* *} \\
0.05^{*} \\
0.02 \\
-0.00 \\
-0.08^{* * *}\end{array}$ & $\begin{array}{l}(3.17) \\
(2.53) \\
(1.00) \\
(-0.13) \\
(-6.39)\end{array}$ & $\begin{array}{c}0.03^{*} \\
0.01 \\
0.01 \\
-0.03^{*} \\
-0.08^{* * *}\end{array}$ & $\begin{array}{l}(2.36) \\
(0.63) \\
(0.64) \\
(-2.00) \\
(-6.11)\end{array}$ & $\begin{array}{c}0.02^{+} \\
0.02 \\
0.01 \\
-0.01 \\
-0.07^{* * *} \\
\end{array}$ & $\begin{array}{l}(1.87) \\
(1.13) \\
(0.57) \\
(-0.96) \\
(-5.72)\end{array}$ & $\begin{array}{c}0.03^{+} \\
0.01 \\
0.01 \\
-0.03^{+} \\
-0.07^{* * *} \\
\end{array}$ & $\begin{array}{l}(1.85) \\
(0.27) \\
(0.54) \\
(-1.76) \\
(-5.71) \\
\end{array}$ \\
\hline $\begin{array}{l}\text { cut } 1 \\
\text { cut2 } \\
\text { cut3 } \\
\text { cut4 } \\
\text { cut5 } \\
\text { cut6 }\end{array}$ & $\begin{array}{c}-2.47^{* *} \\
-1.74 * \\
-1.37 \\
-0.93 \\
-0.29 \\
0.73 \\
\end{array}$ & $\begin{array}{c}(-2.91) \\
(-2.04) \\
(-1.60) \\
(-1.09) \\
(-0.34) \\
(0.85) \\
\end{array}$ & $\begin{array}{c}-4.12^{* * *} \\
-3.35^{* * *} \\
-2.96^{* * *} \\
-2.48^{* *} \\
-1.78^{*} \\
-0.69\end{array}$ & $\begin{array}{l}(-4.69) \\
(-3.82) \\
(-3.36) \\
(-2.81) \\
(-2.02) \\
(-0.78)\end{array}$ & $\begin{array}{c}-1.52^{+} \\
-0.74 \\
-0.35 \\
0.12 \\
0.80 \\
1.88^{*} \\
\end{array}$ & $\begin{array}{c}(-1.78) \\
(-0.86) \\
(-0.40) \\
(0.14) \\
(0.92) \\
(2.16)\end{array}$ & $\begin{array}{c}-3.31^{* * *} \\
-2.52^{* *} \\
-2.11^{*} \\
-1.62^{+} \\
-0.90 \\
0.22\end{array}$ & $\begin{array}{c}(-3.66) \\
(-2.79) \\
(-2.34) \\
(-1.79) \\
(-0.99) \\
(0.24)\end{array}$ \\
\hline Observations & 757 & & 757 & & 757 & & 757 & \\
\hline
\end{tabular}

Notes: Model (1) estimates relationship between job satisfaction and income and work effort. Model (2) adds the occupational identity variable as main explanatory variable. Model (3) shows work characteristics as explanatory variables and model (4) presents the relationship between job satisfaction and occupational identity while also controlling for work characteristics. Heteroscedasticity-robust standard errors clustered on the postal code level. Estimation sample kept identical for all models. Unweighted data.

Source: Own data. 


\section{Table A8: Weighted Regressions with Job Satisfaction as Dependent Variable}

\begin{tabular}{|c|c|c|c|c|c|c|c|c|}
\hline \multirow[b]{2}{*}{$\begin{array}{l}\text { Identity (Independent variable) } \\
\text { Identity index (pca) }\end{array}$} & \multicolumn{2}{|c|}{$\begin{array}{c}(1) \\
\text { Standard } \\
\end{array}$} & \multicolumn{2}{|c|}{$\begin{array}{l}(2) \\
\text { ID Index }\end{array}$} & \multicolumn{2}{|c|}{$\begin{array}{c}(3) \\
\text { WORK CHAR. }\end{array}$} & \multicolumn{2}{|c|}{$\begin{array}{c}(4) \\
\text { WORK CHAR. + ID }\end{array}$} \\
\hline & & & $0.35^{* * *}$ & (7.93) & & & $0.31^{* * *}$ & $(6.53)$ \\
\hline $\begin{array}{l}\text { WDQ (Independent variables) } \\
\text { Task identity: complete products/services } \\
\text { Task identity: complete work process } \\
\text { Task significance: work has influence on others } \\
\text { Task significance: work is significant and important } \\
\text { Task variety: new tasks } \\
\text { Task variety: variety of tasks } \\
\text { Skill variety: work requires various skills } \\
\text { Specialization: work requires specialized skills } \\
\text { Problem-solving: task with no clear solutions } \\
\text { Problem-solving: creativity is important for my work } \\
\text { Social support: meet new people at work } \\
\text { Social support: colleagues are also friends } \\
\text { Autonomy: can make many decisions on my own } \\
\text { Autonomy: abilities allow different approaches }\end{array}$ & & & & & $\begin{array}{c}-0.02 \\
0.05 \\
0.13 \\
0.05 \\
0.24^{* *} \\
-0.18^{+} \\
0.04 \\
0.00 \\
-0.08 \\
0.03 \\
-0.09 \\
0.06 \\
-0.00 \\
0.11\end{array}$ & $\begin{array}{c}(-0.42) \\
(0.72) \\
(1.64) \\
(0.60) \\
(2.95) \\
(-1.90) \\
(0.32) \\
(0.04) \\
(-1.60) \\
(0.44) \\
(-1.51) \\
(1.23) \\
(-0.04) \\
(1.30)\end{array}$ & $\begin{array}{c}-0.02 \\
0.03 \\
0.12 \\
0.02 \\
0.16^{*} \\
-0.16^{+} \\
-0.07 \\
-0.01 \\
-0.05 \\
0.04 \\
-0.08 \\
0.02 \\
0.01 \\
0.07\end{array}$ & $\begin{array}{c}(-0.39) \\
(0.55) \\
(1.63) \\
(0.34) \\
(2.00) \\
(-1.68) \\
(-0.64) \\
(-0.17) \\
(-1.07) \\
(0.57) \\
(-1.37) \\
(0.39) \\
(0.13) \\
(0.99)\end{array}$ \\
\hline $\begin{array}{l}\text { Simple model: Wage, effort (Indep.Variables) } \\
\text { Income (IHS transformed) } \\
\text { Hours worked } \\
\text { Hours worked x Hours worked }\end{array}$ & $\begin{array}{l}0.29^{*} \\
0.04 \\
-0.00\end{array}$ & $\begin{array}{l}(2.18) \\
(1.06) \\
(-1.44)\end{array}$ & $\begin{array}{c}0.08 \\
0.02 \\
-0.00\end{array}$ & $\begin{array}{l}(0.61) \\
(0.34) \\
(-0.71)\end{array}$ & $\begin{array}{c}0.20 \\
0.01 \\
-0.00\end{array}$ & $\begin{array}{l}(1.43) \\
(0.50) \\
(-1.19)\end{array}$ & $\begin{array}{c}0.08 \\
0.00 \\
-0.00\end{array}$ & $\begin{array}{l}(0.53) \\
(0.12) \\
(-0.63)\end{array}$ \\
\hline $\begin{array}{l}\text { Control variables } \\
\text { Gender: female }(0 / 1) \\
\text { Age } \\
\text { Age }^{2} \\
\text { Part-time } \\
\text { Self-employed }(0 / 1)\end{array}$ & $\begin{array}{c}0.16 \\
-0.10^{*} \\
0.14^{*} \\
-0.08 \\
0.32\end{array}$ & $\begin{array}{l}(0.81) \\
(-2.29) \\
(2.56) \\
(-0.20) \\
(1.59)\end{array}$ & $\begin{array}{c}0.26 \\
-0.08^{*} \\
0.11^{*} \\
-0.19 \\
0.31\end{array}$ & $\begin{array}{l}(1.44) \\
(-2.03) \\
(2.36) \\
(-0.42) \\
(1.51)\end{array}$ & $\begin{array}{c}0.35^{+} \\
-0.05 \\
0.07 \\
-0.49 \\
0.34^{+}\end{array}$ & $\begin{array}{c}(1.70) \\
(-1.17) \\
(1.37) \\
(-1.47) \\
(1.69)\end{array}$ & $\begin{array}{c}0.31 \\
-0.05 \\
0.08 \\
-0.41 \\
0.31\end{array}$ & $\begin{array}{l}(1.53) \\
(-1.34) \\
(1.63) \\
(-1.13) \\
(1.52)\end{array}$ \\
\hline $\begin{array}{l}\text { Firm size (base: } 2 \text { to } 20) \text { ) } \\
\text { Solo } \\
21 \text { to } 100 \\
101+\end{array}$ & $\begin{array}{r}-0.37 \\
-0.01 \\
0.10\end{array}$ & $\begin{array}{l}(-1.56) \\
(-0.06) \\
(0.50)\end{array}$ & $\begin{array}{c}-0.42 \\
-0.05 \\
0.20\end{array}$ & $\begin{array}{l}(-1.11) \\
(-0.27) \\
(1.10)\end{array}$ & $\begin{array}{l}-0.28 \\
0.07 \\
0.22\end{array}$ & $\begin{array}{l}(-0.79) \\
(0.32) \\
(1.14)\end{array}$ & $\begin{array}{l}-0.33 \\
0.00 \\
0.25\end{array}$ & $\begin{array}{l}(-0.75) \\
(0.02) \\
(1.38)\end{array}$ \\
\hline $\begin{array}{l}\text { Education (CASMIN scale, base: Secondary) } \\
\text { Primary } \\
\text { Tertiary }\end{array}$ & $\begin{array}{l}-0.45^{* *} \\
0.14\end{array}$ & $\begin{array}{l}(-2.70) \\
(0.73)\end{array}$ & $\begin{array}{c}-0.37^{*} \\
0.25\end{array}$ & $\begin{array}{c}(-2.25) \\
(1.41)\end{array}$ & $\begin{array}{c}-0.41^{*} \\
0.18\end{array}$ & $\begin{array}{c}(-2.56) \\
(1.00)\end{array}$ & $\begin{array}{c}-0.38^{*} \\
0.28\end{array}$ & $\begin{array}{c}(-2.37) \\
(1.57)\end{array}$ \\
\hline $\begin{array}{l}\text { Living (base: Village) } \\
\text { Small town } \\
\text { City } \\
\text { Large city }\end{array}$ & $\begin{array}{l}-0.36 \\
-0.33 \\
-0.42\end{array}$ & $\begin{array}{l}(-1.59) \\
(-1.40) \\
(-1.57)\end{array}$ & $\begin{array}{l}-0.29 \\
-0.32 \\
-0.19\end{array}$ & $\begin{array}{l}(-1.38) \\
(-1.47) \\
(-0.77)\end{array}$ & $\begin{array}{l}-0.24 \\
-0.26 \\
-0.12\end{array}$ & $\begin{array}{l}(-1.08) \\
(-1.26) \\
(-0.51)\end{array}$ & $\begin{array}{c}-0.19 \\
-0.27 \\
0.00\end{array}$ & $\begin{array}{c}(-0.91) \\
(-1.38) \\
(0.01)\end{array}$ \\
\hline $\begin{array}{l}\text { Personality traits } \\
\text { Big five: extraversion } \\
\text { Big five: conscientiousness } \\
\text { Big five: agreeableness } \\
\text { Big five: openness } \\
\text { Big five: neuroticism }\end{array}$ & $\begin{array}{c}-0.01 \\
0.02 \\
0.05 \\
-0.00 \\
-0.10^{* * *}\end{array}$ & $\begin{array}{l}(-0.39) \\
(0.52) \\
(1.47) \\
(-0.04) \\
(-3.70)\end{array}$ & $\begin{array}{c}-0.03 \\
-0.03 \\
0.03 \\
-0.06^{*} \\
-0.09^{* * *}\end{array}$ & $\begin{array}{l}(-1.23) \\
(-1.01) \\
(1.00) \\
(-2.00) \\
(-3.77)\end{array}$ & $\begin{array}{c}-0.02 \\
-0.00 \\
0.03 \\
-0.02 \\
-0.08^{* *}\end{array}$ & $\begin{array}{l}(-0.68) \\
(-0.14) \\
(0.81) \\
(-0.72) \\
(-2.97)\end{array}$ & $\begin{array}{c}-0.03 \\
-0.04 \\
0.02 \\
-0.05^{+} \\
-0.08^{* *}\end{array}$ & $\begin{array}{c}(-1.29) \\
(-1.20) \\
(0.64) \\
(-1.72) \\
(-3.26)\end{array}$ \\
\hline Constant & $4.29 *$ & $(2.42)$ & $8.26^{* * *}$ & (4.23) & $3.98^{*}$ & (2.29) & $7.76^{* * *}$ & $(4.05)$ \\
\hline $\begin{array}{l}\text { Observations } \\
\text { F } \\
\text { Degrees of freedom }\end{array}$ & $\begin{array}{c}757 \\
3.58 \\
756\end{array}$ & & $\begin{array}{l}757 \\
8.08 \\
756\end{array}$ & & $\begin{array}{l}757 \\
4.59 \\
756\end{array}$ & & $\begin{array}{l}757 \\
6.67 \\
756\end{array}$ & \\
\hline
\end{tabular}

Notes: Model (1) estimates relationship between job satisfaction and income and work effort. Model (2) adds the occupational identity variable as main explanatory variable. Model (3) shows work characteristics as explanatory variables and model (4) presents the relationship between job satisfaction and occupational identity while also controlling for work characteristics. Estimation sample kept identical for all models.

Source: Own data. 
Table A9: Weighted Regressions with Occupational Identity Index as Dependent

\section{Variable}

\begin{tabular}{|c|c|c|c|c|c|c|c|c|}
\hline \multirow{3}{*}{$\begin{array}{l}\text { DV: Identity Index } \\
\text { WDQ variables (Independent variables) }\end{array}$} & \multicolumn{2}{|c|}{$(1)$} & \multirow{2}{*}{\multicolumn{2}{|c|}{$\begin{array}{c}\text { (2) } \\
\text { WDQ.+TYPE }\end{array}$}} & \multirow{2}{*}{\multicolumn{2}{|c|}{$\begin{array}{c}(3) \\
\text { POSITION }\end{array}$}} & \multirow{2}{*}{\multicolumn{2}{|c|}{$\begin{array}{c}\text { (4) } \\
\text { WDQ. + POS. }\end{array}$}} \\
\hline & \multicolumn{2}{|c|}{ WORK TYPE } & & & & & & \\
\hline & & & \multicolumn{2}{|c|}{ WDQ. + I YPE } & & \multirow[b]{2}{*}{-0.08} & \multirow{2}{*}{$(-1.05)$} \\
\hline Task identity: complete products/services & & & -0.01 & $(-0.12)$ & & & & \\
\hline Task identity: complete work process & & & 0.04 & $(0.53)$ & & & 0.04 & $(0.46)$ \\
\hline Task significance: work has influence on others & & & 0.04 & $(0.34)$ & & & 0.02 & $(0.19)$ \\
\hline Task significance: work is significant and important & & & 0.08 & $(0.77)$ & & & 0.10 & $(0.92)$ \\
\hline Task variety: new tasks & & & $0.25^{*}$ & $(2.31)$ & & & $0.29 *$ & $(2.57)$ \\
\hline Task variety: variety of tasks & & & -0.07 & $(-0.55)$ & & & -0.07 & $(-0.56)$ \\
\hline Skill variety: work requires various skills & & & $0.35^{*}$ & $(2.35)$ & & & $0.38^{*}$ & $(2.44)$ \\
\hline Specialization: work requires specialized skills & & & 0.06 & $(0.55)$ & & & 0.03 & $(0.29)$ \\
\hline Problem-solving: task with no clear solutions & & & -0.09 & $(-1.41)$ & & & $-0.13^{+}$ & $(-1.87)$ \\
\hline Problem-solving: creativity is important for my work & & & -0.04 & $(-0.45)$ & & & -0.05 & $(-0.59)$ \\
\hline Social support: meet new people at work & & & -0.04 & $(-0.46)$ & & & -0.08 & $(-0.94)$ \\
\hline Social support: colleagues are also friends & & & $0.13^{+}$ & (1.96) & & & $0.14^{*}$ & $(1.99)$ \\
\hline Autonomy: can make many decisions on my own & & & -0.04 & $(-0.38)$ & & & -0.05 & $(-0.49)$ \\
\hline Autonomy: abilities allow different approaches & & & 0.12 & $(1.16)$ & & & 0.03 & $(0.29)$ \\
\hline \multicolumn{9}{|l|}{ Control variables in models using WDQ } \\
\hline Admin/Sales & -0.63 & $(-1.58)$ & -0.23 & $(-0.73)$ & & & $-1.03 *$ & $(-2.21)$ \\
\hline Management, no craft & 0.28 & $(0.78)$ & -0.10 & $(-0.33)$ & & & -0.07 & $(-0.25)$ \\
\hline Craft, with admin & -0.34 & $(-0.84)$ & -0.13 & $(-0.34)$ & & & -0.04 & $(-0.10)$ \\
\hline Management, with craft & 0.57 & $(1.16)$ & 0.25 & $(0.60)$ & & & 0.19 & $(0.42)$ \\
\hline \multicolumn{9}{|l|}{ Vocational development stage (base: Master crafter) } \\
\hline Apprentice & & & & & $-0.73^{+}$ & $(-1.74)$ & 0.13 & $(0.28)$ \\
\hline Journey(wo)man & & & & & -0.19 & $(-0.74)$ & -0.08 & $(-0.31)$ \\
\hline Senior Journey(wo)man & & & & & -0.03 & $(-0.09)$ & -0.36 & $(-1.26)$ \\
\hline \multicolumn{9}{|l|}{ Control variables } \\
\hline Income (IHS transformed) & & & $0.39^{+}$ & $(1.90)$ & & & $0.55^{+}$ & $(1.83)$ \\
\hline Gender: female $(0 / 1)$ & -0.40 & $(-1.18)$ & 0.07 & $(0.24)$ & -0.30 & $(-0.75)$ & 0.34 & (1.04) \\
\hline Age & 0.00 & $(0.01)$ & 0.01 & $(0.25)$ & -0.04 & $(-0.67)$ & 0.01 & $(0.22)$ \\
\hline $\mathrm{Age}^{2}$ & -0.01 & $(-0.09)$ & -0.03 & $(-0.41)$ & 0.03 & $(0.45)$ & -0.02 & $(-0.24)$ \\
\hline Self-employed $(0 / 1)$ & 0.13 & $(0.44)$ & -0.04 & $(-0.18)$ & 0.42 & $(1.35)$ & -0.02 & $(-0.08)$ \\
\hline \multicolumn{9}{|l|}{ Firm size (base: 2 to 20 )) } \\
\hline Solo & 0.12 & $(0.20)$ & 0.18 & $(0.37)$ & -0.09 & $(-0.13)$ & 0.25 & $(0.37)$ \\
\hline 21 to 100 & 0.27 & $(1.12)$ & 0.25 & $(1.09)$ & 0.34 & $(1.31)$ & 0.27 & $(1.06)$ \\
\hline $101+$ & -0.03 & $(-0.11)$ & -0.09 & $(-0.35)$ & 0.10 & $(0.32)$ & 0.08 & $(0.33)$ \\
\hline \multicolumn{9}{|l|}{ Education (CASMIN scale, base: Secondary) } \\
\hline Primary & -0.30 & $(-1.33)$ & -0.12 & $(-0.60)$ & -0.24 & $(-0.98)$ & -0.17 & $(-0.81)$ \\
\hline Tertiary & -0.26 & $(-0.80)$ & -0.31 & $(-1.11)$ & -0.02 & $(-0.06)$ & -0.33 & $(-0.92)$ \\
\hline \multicolumn{9}{|l|}{ Living (base: Village) } \\
\hline Small town & -0.32 & $(-1.29)$ & -0.14 & $(-0.59)$ & -0.38 & $(-1.36)$ & -0.05 & $(-0.17)$ \\
\hline City & -0.17 & $(-0.71)$ & 0.03 & $(0.12)$ & -0.14 & $(-0.54)$ & 0.21 & $(0.83)$ \\
\hline Large city & $-0.89^{*}$ & $(-2.07)$ & -0.45 & $(-1.10)$ & $-0.62^{+}$ & $(-1.68)$ & -0.17 & $(-0.46)$ \\
\hline \multicolumn{9}{|l|}{ Personality traits } \\
\hline Big five: extraversion & 0.05 & $(1.44)$ & 0.03 & $(1.07)$ & 0.05 & $(1.37)$ & 0.05 & $(1.58)$ \\
\hline Big five: conscientiousness & $0.15^{* * *}$ & $(3.31)$ & $0.09^{*}$ & $(2.19)$ & $0.11^{*}$ & $(2.16)$ & 0.07 & $(1.58)$ \\
\hline Big five: agreeableness & 0.05 & $(1.30)$ & 0.03 & $(0.69)$ & 0.04 & $(0.92)$ & 0.01 & $(0.12)$ \\
\hline Big five: openness & $0.15^{* * *}$ & $(3.91)$ & $0.09^{*}$ & $(2.31)$ & $0.16^{* * *}$ & $(3.41)$ & $0.09^{*}$ & $(2.11)$ \\
\hline Big five: neuroticism & -0.04 & $(-1.27)$ & -0.03 & $(-0.82)$ & $-0.07^{*}$ & $(-1.99)$ & -0.05 & $(-1.42)$ \\
\hline Constant & $-5.91 * * *$ & $(-4.72)$ & $-11.44^{* * *}$ & $(-5.90)$ & $-3.85^{* *}$ & $(-2.77)$ & $-10.89^{* * *}$ & $(-3.65)$ \\
\hline Observations & 757 & & 757 & & 559 & & 559 & \\
\hline $\mathrm{F}$ & 4.01 & & 4.86 & & 3.55 & & 3.81 & \\
\hline Degrees of freedom & 756 & & 756 & & 558 & & 558 & \\
\hline
\end{tabular}

Notes: Model (1) analyzes the relationship between occupational identity and main activity at work, model (2) between occupational identity and work characteristics. Models (3) and (4) repeat this analysis with focus on the relationship between occupational identity and vocational position. Estimation sample kept identical in models (1) and (2) but is lower for models (3) and (4) due to missing data concerning occupational position.

Source: Own data. 